\title{
REVIEW
}

\section{Resistance to targeted treatment of gastroenteropancreatic neuroendocrine tumors}

\author{
Matthias Beyens ${ }^{1,2}$, Timon Vandamme1,2,3, Marc Peeters' ${ }^{1}$, Guy Van Camp ${ }^{1,2}$ and Ken Op de Beeck ${ }^{1,2}$ \\ ${ }^{1}$ Center of Medical Genetics, University of Antwerp and Antwerp University Hospital, Antwerp, Belgium \\ ${ }^{2}$ Center for Oncological Research, University of Antwerp, Antwerp, Belgium \\ ${ }^{3}$ Section of Endocrinology, Department of Internal Medicine, Erasmus Medical Center, Rotterdam, the Netherlands \\ Correspondence should be addressed to G Van Camp: guy.vancamp@uantwerpen.be
}

\begin{abstract}
The mammalian target of rapamycin (mTOR) is part of the phosphoinositide-3-kinase (PI3K)/protein kinase B (Akt)/mTOR signaling. The PI3K/Akt/mTOR pathway has a pivotal role in the oncogenesis of neuroendocrine tumors (NETs). In addition, vascular endothelial growth factor (VEGF) and platelet-derived growth factor (PDGF) drive angiogenesis in NETs and therefore contributes to neuroendocrine tumor development. Hence, mTOR and angiogenesis inhibitors have been developed. Everolimus, a

first-generation mTOR inhibitor, has shown significant survival benefit in advanced gastroenteropancreatic NETs. Sunitinib, a pan-tyrosine kinase inhibitor that targets the VEGF receptor, has proven to increase progression-free survival in advanced pancreatic NETs. Nevertheless, primary and acquired resistance to rapalogs and sunitinib has limited the clinical benefit for NET patients. Despite the identification of multiple molecular mechanisms of resistance, no predictive biomarker has made it to the clinic. This review is focused on the mTOR signaling and angiogenesis in NET, the molecular mechanisms of primary and acquired resistance to everolimus and sunitinib and how to overcome this resistance by alternative drug compounds.
\end{abstract}

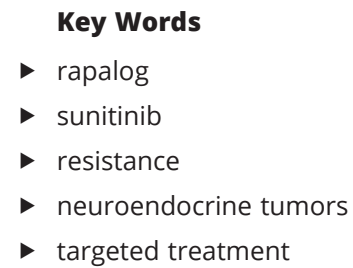

\section{Introduction}

In the late 1970s, the cellular mammalian target of rapamycin (mTOR) protein complex was discovered along with its natural inhibitor rapamycin. Rapamycin is isolated from Streptomyces hygroscopicus and named after the ancient residents of its discovery place (Easter Island, Rapa Nui) (Sehgal et al. 1975, Vézina et al. 1975, Baker et al. 1978, Singh et al. 1979). In mammals, rapamycin has strong antifungal, immune-suppressive and anticancer properties via inhibition of mTOR complex 1 and 2 (mTORC1 and mTORC2), two protein complexes part of the phosphoinositide-3-kinase/Akt/mammalian target of rapamycin (PI3K/Akt/mTOR) pathway (Saxton \& Sabatini 2017). The PI3K/Akt/mTOR pathway plays a pivotal role by regulating cell growth, proliferation, survival and protein synthesis in gastroenteropancreatic neuroendocrine tumors (GEP-NETs) (Missiaglia et al. 2010, Jiao et al. 2011, Kasajima et al. 2011). GEP-NETs include small intestinal NETs (siNETs) and NETs arising of the pancreas (pNETs). siNETs are the most common tumor in the small intestine and have an incidence of 1.05 per 100,000 person years in the National Cancer Institute Surveillance, Epidemiology and End Results (SEER) registry (Dasari et al. 2017). pNETs comprise only $1-2 \%$ of all pancreatic neoplasms, with an incidence of about 0.48 per 100,000 person years (Eriksson \& Öberg 2000, Verbeke 2010). The median overall survival (mOS) for patients with pNET is 3.6 years https://erc bioscientifica com https://doi.org/10.1530/ERC-18-0420
(C) 2019 Society for Endocrinology Published by Bioscientifica Ltd. Printed in Great Britain 
(Dasari et al. 2017). siNETs have a better mOS, ranging from 14 years in localized disease to 5.83 years in metastatic setting (Dasari et al. 2017). The contributing role of the $\mathrm{PI} 3 \mathrm{~K} / \mathrm{Akt} / \mathrm{mTOR}$ signaling in NET carcinogenesis has led to the introduction of the mTOR inhibitor everolimus, a so-called a rapalog, in the clinic. However, primary and acquired resistance to everolimus may limit their efficacy as single treatment modality (Yao et al. 2013, Vandamme et al. 2016). Acquired resistance is the mechanism where patients who initially respond to everolimus and other rapalogs, later relapse and develop resistance, whereas primary resistance can be observed as patients that do not respond at all. In addition to the involvement of PI3K/Akt/mTOR, vascular endothelial growth factor (VEGF) and PDGF drive angiogenesis in GEP-NETs and therefore contributes to tumor development (Oberg et al. 2013). Therefore, sunitinib, a pan-tyrosine kinase inhibitor that targets the VEGF receptor, was developed as a treatment modality for pNETs. As is the case for everolimus, resistance to sunitinib has been described (Gotink et al. 2011). In this review, we evaluate the mode of action of everolimus and sunitinib in NETs. We summarize the known molecular mechanisms inducing primary and acquired resistance to these targeted drugs. Finally, we briefly describe multiple treatment modalities and ongoing clinical trials to overcome the known resistance mechanisms.

\section{PI3K/Akt/mTOR signaling}

\section{PI3K/Akt/mTOR signaling in the normal cell}

The PI3K/Akt/mTOR signaling cascade plays a pivotal role in cell growth, proliferation, survival and protein synthesis. The physiological intracellular signaling cascade is triggered through binding of growth factors to their respective receptors, either receptor tyrosine kinases or G-protein coupled receptors at the cell's membrane (Fig. 1). One such signal transduction involves the activation of phosphoinositide 3-kinase (PI3K) lipid kinase (Fruman \& Rommel 2014). PI3K phosphorylates the membrane-bound phosphatidylinositol-4-5-biphosphate $\left(\mathrm{PIP}_{2}\right)$ to generate phosphatidylinositol-3,4,5-triphosphate $\left(\mathrm{PIP}_{3}\right)$ (Thorpe et al. 2015). PI3K activity is regulated by phosphatase and tensin homologue (PTEN), which converts $\mathrm{PIP}_{3}$ back to $\mathrm{PIP}_{2}$ (Vanhaesebroeck et al. 2012). $\mathrm{PIP}_{3}$ effectors are proteins with pleckstrin homology (PH) domains. One such effector is the serine/threonine kinase Akt, also known as protein kinase B (PKB) (Vanhaesebroeck et al. 2012). Upon PIP ${ }_{3}$ PH domain binding, Akt localizes to the membrane and gets activated by phosphoinositidedependent kinase 1 (PDK1) phosphorylation at Thr308 (Stokoe et al. 1997). Akt has a myriad of downstream substrates; glycogen synthase kinase 3 (GSK3, insulin signaling), B-cell lymphoma 2 (Bcl-2) antagonist of cell death (BAD, pro-apoptotic signaling), p21 and p27 (cell cycle regulation), Forkhead box O (FOXO transcription factor) and mTOR (Cross et al. 1995, Datta et al. 1997, Brunet et al. 1999, Zhou et al. 2001, Shin et al. 2002, Saxton \& Sabatini 2017).

\section{Two mTOR protein complexes}

mTOR exerts its kinase activity within two distinct multiprotein complexes designated mTORC1 and mTORC2 with both a combination of unique and common components (Fig. 2). mTORC1 is built around its main protein mTOR and different subunits, regulatoryassociated protein of mTOR (Raptor), and mammalian

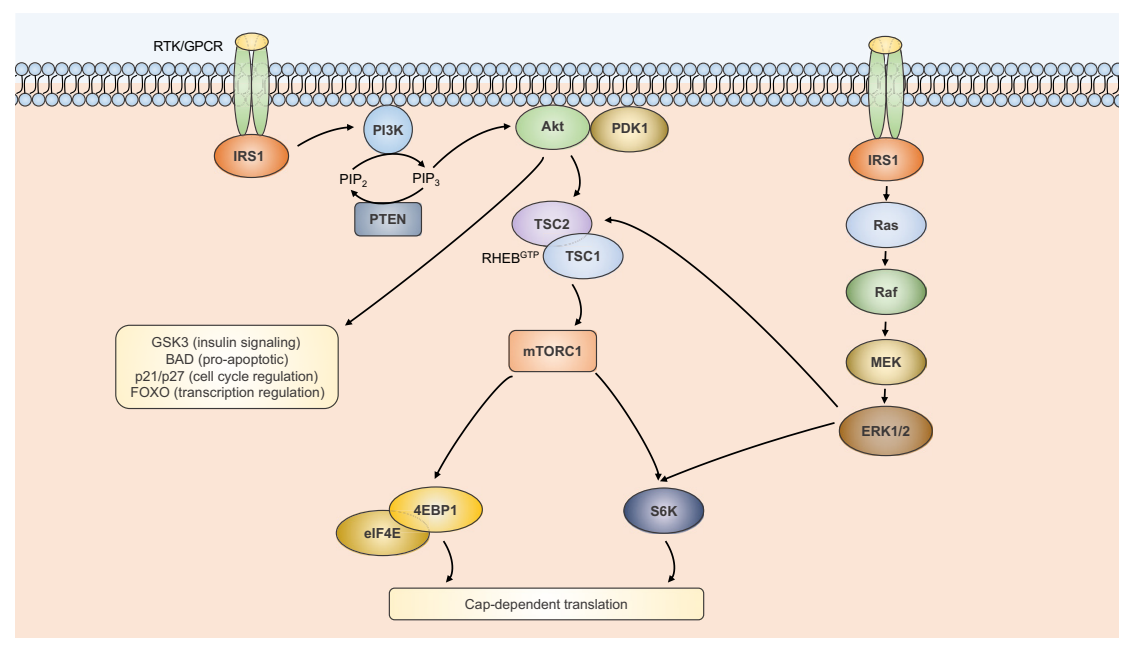

\section{Figure 1}

Schematic representation of the PI3K/Akt/mTOR pathway. Important components involved in the $\mathrm{PI}$ KK/Akt/mTOR pathway and their interactions in a cellular context are depicted. The components upstream of mTOR regulate insulin signaling, pro-apoptotic signals, cell cycle regulation and transcription factors. Downstream of mTOR are the effectors that stimulate the cap-dependent translation of proteins. https://erc bioscientifica.com https://doi.org/10.1530/ERC-18-0420
(C) 2019 Society for Endocrinology Published by Bioscientifica Ltd. Printed in Great Britain 


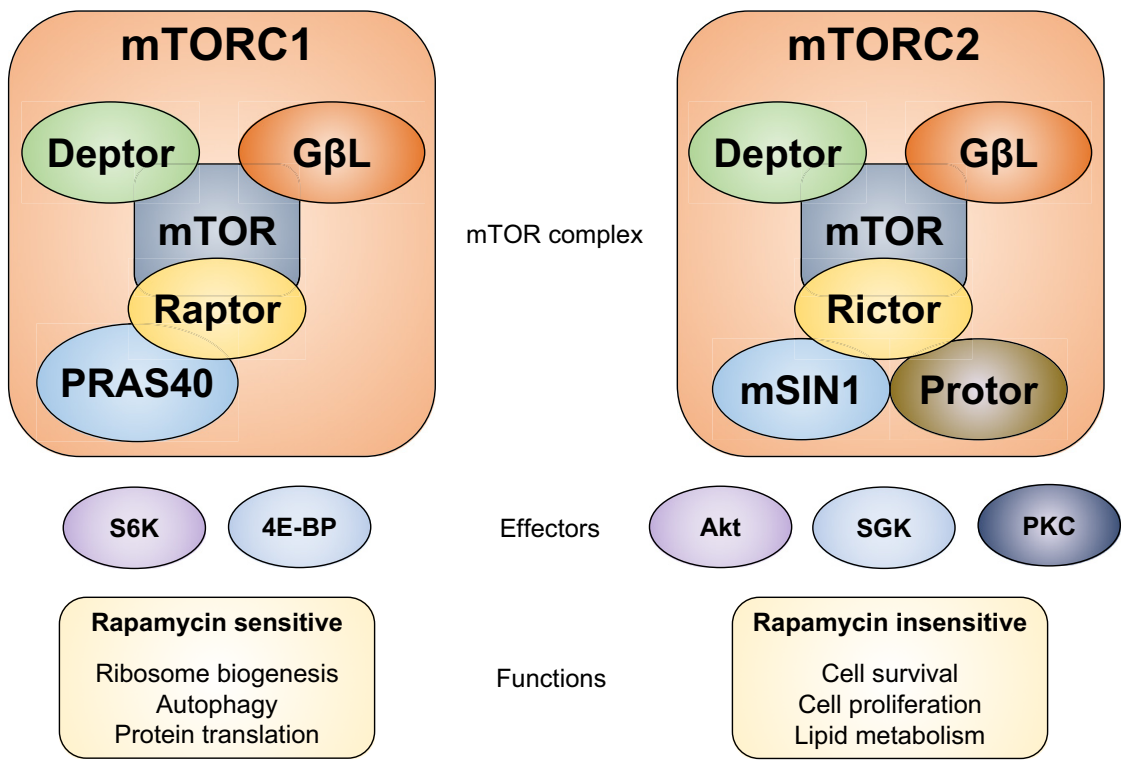

\section{Figure 2}

Two distinct mTOR complexes. mTOR is the common protein in two different complexes, mTORC1 and mTORC2. The first mTOR complex, mTORC1, contains Deptor, G $\beta$ L, PRAS40 and Raptor. The second complex, mTORC2, contains Deptor, $\mathrm{G} \beta \mathrm{L}$, mSIN1, Protor and Rictor. Every complex has its own downstream effectors and hence specific functions. lethal with SEC13 protein 8 (mLST8), plus two inhibitors $40 \mathrm{kDa}$ proline-rich Akt substrate (PRAS40) and DEP domain-containing mTOR-interacting protein (DEPTOR) (Saxton \& Sabatini 2017). Once mTORC1 is activated, it can regulate the activity of eukaryotic translation initiation factor 4E (eIF4E)-binding proteins (4E-BPs) and ribosomal S6 kinase 1 and 2 (S6K1/2) (Fig. 3A). Under basal conditions, 4E-BP1 remains bound to eIF4E in its hypo-phosphorylated form. Upon activation, 4E-BP1 is phosphorylated at Thr37, Thr46, Thr70 and Ser65 by mTOR and induces dissociation of the 4E-BP-eIF4E complex. eIF4E is not inhibited anymore and stimulates the initiation of cap-dependent mRNA translation (Gingras et al. 2001). Further, S6K1 is phosphorylated at Thr389 by mTORC1 and at Thr229 by PDK1 (Ma \& Blenis 2009). Activation of $\mathrm{S} 6 \mathrm{~K} 1 / 2$ promotes the cells translational machinery and interacts with transcription factors to promote transcription of cell cycle regulation genes. On the other hand, mTORC2 is assembled with its main protein mTOR and rapamycin-insensitive subunit (Rictor), and mLST8, plus one inhibitor DEPTOR (Saxton \& Sabatini 2017) (Fig. 2). mTORC2 is a distinct complex from mTORC1, and it regulates the activity of Akt via a feedback circuit (Yang et al. 2006; Fig. 3A). Maximal allosteric kinase activation of Akt is accomplished by mTORC2-dependent Ser473 phosphorylation (Sarbassov et al. 2005). Another regulatory function of mTORC2 is the phosphorylation of serum and glucocorticoid-activated kinase 1 (SGK1), thereby regulating cell proliferation and apoptosis via FOXO transcription factors (Mori et al. 2014). Furthermore, the Rictor component of the complex causes insensitivity to rapalogs (Sarbassov et al. 2004), although prolonged treatment can inhibit mTORC2 in some cell types. mTORC2 is mainly involved in cell proliferation, survival and migration via cytoskeletal remodeling (Arias et al. 2015). In addition, mTORC2 promotes tumorigenesis via stimulation of the lipid synthesis (Guri et al. 2017)

\section{PI3K/Akt/mTOR signaling in neuroendocrine tumors}

In recent studies, alterations in genes and encoded products involved in the PI3K/Akt/mTOR signaling were linked both in familial and sporadic NET cases. Familial NETs are rarer than sporadic ones and often have incomplete penetrance. These familial syndromes are caused by germline mutations in genes involved in the PI3K/Akt/mTOR pathway, such as Cowden syndrome (PTEN), tuberous sclerosis (TSC1/2), Von Hippel-Lindau (VHL), multiple endocrine neoplasia-1 (MEN1) and neurofibromatosis (NF1) (Crona \& Skogseid 2016). Sporadic NETs are more frequent, and the tumors harbor somatic mutations in genes associated to the PI3K/Akt/mTOR signaling. Next-generation sequencing experiments revealed alterations in 14-29\% of the pNET patients having mutations in the mTOR pathway genes and $21-44 \%$ somatic inactivating mutations in MEN1 (Jiao et al. 2011, Vandamme et al. 2019). Furthermore, up to $43 \%$ of the patients have a mutually exclusive mutation in ATRX or DAXX (Jiao et al. 2011). In addition, a recent publication demonstrated the presence of $D A X X$ mutations in circulating tumor DNA of pNET patients (Boons et al. 2018). Losses of chromosomal regions including MEN1 are observed in $70 \%$ of sporadic pNETs 


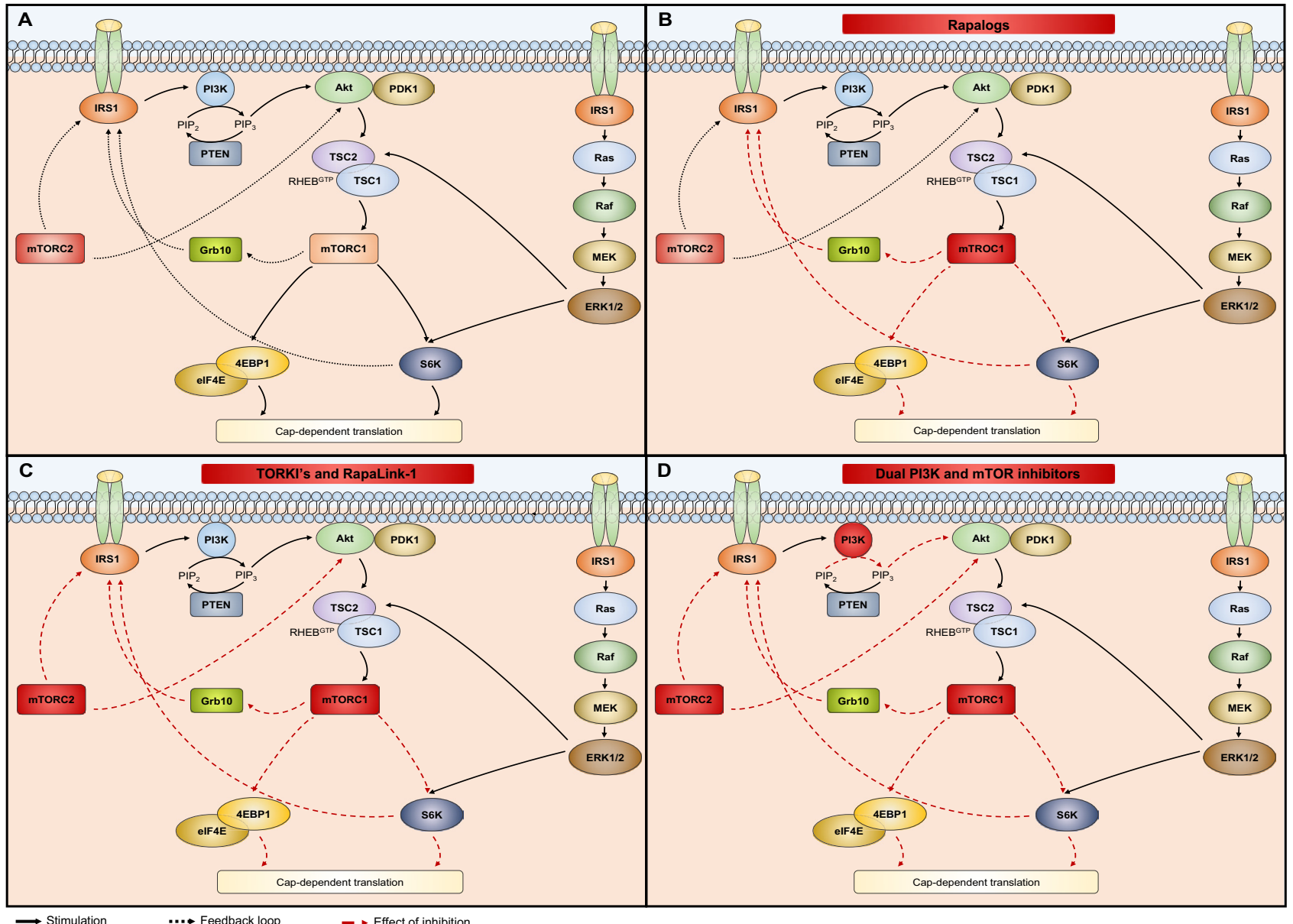

Figure 3

$\mathrm{PISK} / \mathrm{Akt} / \mathrm{mTOR}$ feedback circuits and mechanism of action of pharmacological compounds. Positive feedback is shown in black, full arrows, while negative feedback is depicted through black, dashed arrows. Effect of inhibitors is shown through red, dashed arrows. (Panel A) The physiological feedback circuit of the PI3K/Akt/mTOR signaling. mTORC1 activity is modulated by Akt through tuberous sclerosis complex (TSC). TSC includes three proteins: Hamartin (TSC1), Tuberin (TSC2) and TBC1D7 (Inoki et al. 2002, Dibble et al. 2012). TSC has a small GTPase-activating protein (GAP) activity and inhibits Ras homologue enriched in brain (RHEB) kinase. Phosphorylation of TSC2 by Akt, weakens its interaction with TSC1 and destabilizes TSC2. The phosphorylation relieves the TSC2 inhibition of RHEB and allows it to activate mTORC1 kinase activity. Simultaneously, Akt phosphorylates PRAS40 at Thr246, and mTORC1 phosphorylates PRAS40 at Ser183 and Ser221, which induces its dissociation and loss of inhibition of mTORC1 (Wang et al. 2012). The Ras-ERK-MAPK signaling pathway can activate mTORC1 by ERK-directed phosphorylation of TSC2 at Ser664 (Ma et al. 2005) or phosphorylation of S6 kinase 1 (S6K1), which on its turn phosphorylates TSC2 at Ser1798 (Roux et al. 2004). In addition, mTORC2 requires an intact TSC1/2 complex for activation by growth factors, as TSC1/2 associates with Rictor and activates mTORC2 independently of the GAP activity of TSC2 toward RHEB. A negative feedback on mTORC1 occurs through proteasomal degradation of insulin receptor substrate 1 and 2 (IRS1 and IRS2), through S6K1-dependent phosphorylation and through phosphorylation of growth factor receptor-bound protein 10 (Grb10) (Harrington et al. 2004, Shah et al. 2004, Hsu et al. 2011, Yu et al. 2011). (Panel B) Inhibition of mTORC1 by rapalogs. (Panel C) Inhibition of mTORC1 and mTORC2 by mTOR kinase inhibitors (TORKis) and the third-generation small molecules, such as RapaLink-1. (Panel D) Inhibition of mTORC1, mTORC2 and PI3K by dual PI3K and mTOR inhibitors.

(Scarpa et al. 2017). PHLDA3, a potent inhibitor of Akt activation, is inactivated by loss of heterozygosity in $72 \%$ of pNETs (Kawase et al. 2009, Ohki et al. 2014). In addition, Scarpa et al. identified a gain-of-function gene fusion that indirectly activates mTOR's kinase activity. In 3\% of the examined pNETs, somatic Ewing Sarcoma Breakpoint Region 1 (EWSR1) fusion events with BEND2 or FLI-1 were detected (Scarpa et al. 2017). Another structural variation includes the amplification of persephin ( $P S P N)$ in $13 \%$ of the investigated samples (Scarpa et al. 2017). PSPN binds the rearranged during transfection (RET) receptor and activates PI3K catalytic subunit alfa (PI3KCA) (Lindahl et al. 2001). Abnormal activation of the mTOR signaling in pNET is also driven by dysfunctional tyrosine kinase receptors, such as EGFR, VEGFR, PDGFR, FGFR3 and IGF-1R, all activating the mTOR axis (Capdevila \& Tabernero 2011). Most of the alterations have been associated with known oncogenes and tumor suppressors
C) 2019 Society for Endocrinology Published by Bioscientifica Ltd. Printed in Great Britain 
upstream of mTOR, eventually leading to an increase in mTOR activity. Nevertheless, there is evidence to suggest that mTORs downstream effectors 4E-BPs and S6Ks are also altered in NETs. Gene expression profiling and immunohistochemistry (IHC) staining studies in pNETs have shown overexpression of mTOR in $67 \%$, aberrant activation of Akt in $61 \%$ and positive correlation of mTOR downstream targets protein levels and phosphorylation status with clinicopathological variables and patient prognosis, including 4E-BP1, S6K and eIF4E (Ghayouri et al. 2010, Shida et al. 2010, Kasajima et al. 2011). Loss or severe reduction of expression of negative regulatory components of mTOR signaling, such as TSC2 and PTEN, was observed in multiple independent pNET studies (Perren et al. 2000, Missiaglia et al. 2010, Scarpa et al. 2017). TSC2 expression is lowered or absent in $35 \%$ of pNETs in comparison to normal pancreatic islet cells. Similarly, PTEN expression is lost in $7-29 \%$ of pNETs. In another study involving 72 pNETs, PTEN expression levels were lowered or absent in $60 \%$ of the samples. TSC2 or PTEN levels in pNETs are of clinical relevance as both gene products correlate to a less favorable disease-free, progression-free and overall survival outcome (Missiaglia et al. 2010). More recently, the role of phosphorylated (p-) mTOR in the expression of somatostatin receptor $2 \mathrm{~A}$ (SSTR2A) and insulin growth factor receptor 1 (IGF-1R) was evaluated via IHC staining as a prognostic marker in 64 GEP-NETs (Lamberti et al. 2017). Low SSTR2A expression and higher p-mTOR levels were associated with advanced disease.

\section{Angiogenesis signaling}

\section{Angiogenesis signaling in the normal cell}

Angiogenesis is a biological process by which novel microvessels are formed (Jain 2003). This process is essential in providing the tissue with sufficient oxygen and nutrients. Physiologically, angiogenesis occurs during embryonal growth and development of organs (Sato 1991, Folkman \& Shing 1992). This strictly regulated process is balanced by pro-angiogenic and anti-angiogenic factors, and among these are VEGF and platelet-derived growth factor (PDGF). VEGF binds to tyrosine kinase receptors (TKRs), including Flt-1 (VEGFR-1), KDR/Flk-1 (VEGFR-2) and Flt-4 (VEGFR-3) (Alitalo et al. 1992, de Vries et al. 1992, Mendel et al. 2003). These TKRs are expressed on the membranes of endothelial cells, vascular smooth muscle cells and monocytes/macrophages (Alitalo et al. 1992, Jakeman et al. 1992, Quinn et al. 1993). The production of
VEGF is regulated by local oxygen availability. The hypoxiainducible factor-1 (HIF-1) binds the VEGF promoter and stimulates gene transcription and mRNA stability. HIF-1 consists of two subunits, HIF- $1 \alpha$ and aryl hydrocarbon receptor nuclear translocator or HIF-1 $\beta$ (Wang \& Semenza 1995). Several studies showed the pivotal role of HIF-1 $\alpha$ in cellular and developmental oxygen homeostasis (Iyer et al. 1998). Under normoxic condition, HIF- $1 \alpha$ is hydroxylated at two proline residues. This reaction is oxygen dependent. Upon hydroxylation, VHL recognizes and ubiquitinates HIF- $1 \alpha$ for proteasomal degradation (Maxwell et al. 1999, Richard et al. 2013, Kobayashi et al. 2016). Under hypoxic conditions, the proline residues of HIF- $1 \alpha$ are not hydroxylated. Subsequently, HIF- $1 \alpha$ escapes the negative regulation of VHL protein. HIF- $1 \alpha$ translocates to the nucleus, dimerizes with HIF-1 $\beta$ and binds gene promoters with a responsive element (Iyer et al. 1998). This binding modulates the expression of genes involved in angiogenesis, proliferation, glucose metabolism and $\mathrm{pH}$ regulation (Iyer et al. 1998, Liao \& Johnson 2007). In conclusion, VEGF not only stimulates the new formation of microvessels, it also ensures vascularization under hypoxic conditions. Another important regulatory component in angiogenesis is the PDGF. PDGF has 18-24\% homology with VEGF (Lyons et al. 1988, Keck et al. 1989). Nevertheless, PDGF binds other receptors, including PDGF- $\alpha$ and PDGF- $\beta$. These two TKRs are expressed by endothelial cells and smooth muscle cells, but mainly pericytes (Battegay et al. 1994, Heldin \& Westermark 1999).

\section{Angiogenesis signaling in neuroendocrine tumors}

The demand of high vascularization density for nutrient delivery to the growing tumor is one of the hallmarks of cancer (Hanahan \& Weinberg 2011). Pinato et al. demonstrated the presence of an important angiogenic expressionsignaturein GEP-NETsthroughimmunostaining of HIF- $1 \alpha$, VEGF-A and carbonic anhydrases IX (Ca-IX) (Pinato et al. 2014). Well-differentiated GEP-NETs are highly vascularized by significant upregulation of HIF- $1 \alpha$. The activation of HIF- $1 \alpha$ is driven by genetic inactivation of VHL protein and the stimulating hypoxic conditions that are typically present in GEP-NET cellular environments (Fig. 4A and B). Chromogranin $\mathrm{A}$ is a protein that is commonly expressed and secreted by GEP-NETs. CgA positivity on immunohistochemistry is a diagnostic hallmark of GEP-NETs, while serum CgA is used as a biomarker for follow-up of GEP-NET patients (Kanakis \& Kaltsas 2012, Oberg et al. 2017, 


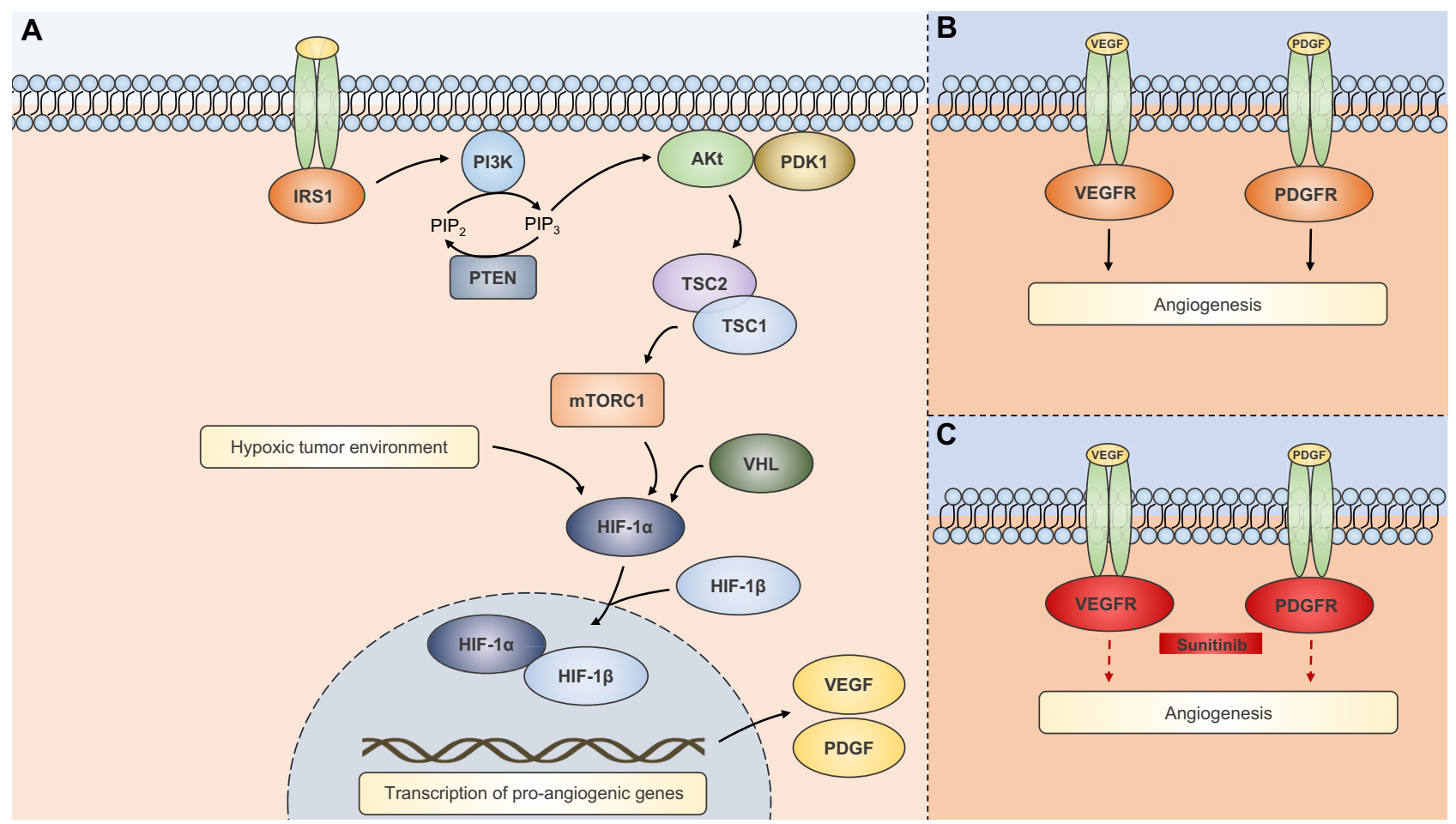

\section{Figure 4}

Schematic representation of the angiogenesis pathway. Important components involved in the angiogenesis pathway and their interactions in a cellular context are depicted in neuroendocrine tumor cells (panel A), endothelial cells (VEGFR) and pericytes (PDGFR) (panel B). Sunitinib is targeting the tyrosine kinase receptors, including VEGFR and PDGFR (panel C).

Hofland et al. 2018). This circulating biomarker has been associated with angiogenesis (Conteduca et al. 2014). Welldifferentiated pNETs are highly vascularized tumors and express high levels of VEFG, VEGFR-2 and -3, PDGFR- $\alpha$ and - $\beta$ (Couvelard \& Sauvanet 2008). In the process of pNET dedifferentiation, VEGF expression is lost and the vascularization density decreases (Couvelard et al. 2005). This so-called neuroendocrine paradox is only reported in pNETs, where high microvessel density might serve as a marker for well-differentiated tumors. Nonetheless, no association between VEGF expression and patient survival exist (Couvelard et al. 2005).

\section{Rapalog therapy in neuroendocrine tumors}

\section{Mechanism of action of rapalogs}

Rapalogs inhibit the mTORC1-dependent activation of S6K1/2 and 4E-BP1. These effectors regulate capdependent protein translation of key proteins involved in cell cycle progression, including cyclin D1, c-MYC and HIF-1 $\alpha$ (Figs 1 and 2; Faivre et al. 2006). Consequently, mTORC1 inhibitors suppress protein translation, growth of cells, limit cell progression through cell cycle G1-S phase inhibition, induce autophagy, modulate apoptotic processes and disrupt angiogenesis (Saxton \& Sabatini 2017). To inhibit mTORC1 activity, rapalogs bind to the intracellular FK506-binding protein $12 \mathrm{kDa}$ (FKBP12). The FKBP12-rapalog complex binds to mTOR at the FRB domain (Chen et al. 1995, Choi et al. 1996). Subsequently, this complex binding induces conformational changes and allosteric inhibition of mTOR, resulting in dissociation of raptor from mTOR in mTORC1 (Oshiro et al. 2004). The altered mTORC1 structure drastically reduces the accessibility of the catalytic cleft and reduces its kinase activity on downstream components including S6K1/2 and 4E-BP1 (Fig. 3B). However, cell-type-specific treatment effects on phosphorylation status exist (Choo et al. 2008). In addition, auto-phosphorylation of the Ser2481 mTOR residue is significantly reduced and further decreases the kinase activity (Soliman et al. 2010). In 2006, it has been shown that short-term rapalogs therapy inhibits mTORC1, while mTORC2, assembled with rapalog-insensitive component Rictor, was not inhibited by short-term treatment (Jacinto et al. 2004). However, recent studies show that long-term rapamycin treatment inhibits both mTORC1 and mTORC2 as the FKBP12rapalog complex directly binds mTOR under long-term 
treatment and prevents its assembly to the multiprotein mTOR complex (Rosner \& Hengstschläger 2008, Schreiber et al. 2015).

\section{Clinical trials evaluating rapalog safety and efficacy in neuroendocrine tumors}

In 2008, O'Donnell et al. have published the first phase I study evaluating the pharmacokinetic and pharmacodynamics of everolimus in patients with advanced solid tumors (O'Donnell et al. 2008). In the same year, Yao et al. have reported the first phase II study evaluating everolimus in NETs (Yao et al. 2008). This study included 30 patients with carcinoids and 30 patients with pNETs who were given a combination of octreotide long-acting release (LAR) and everolimus. Radiological response rates (RRs) were 17 and $27 \%$ with a progression-free survival rate (PFS) of 63 and 50 weeks, respectively. Patients treated with everolimus obtained a higher RR (30 vs 13\%) and prolonged PFS (72 vs 50 weeks).

Anti-proliferative activity of everolimus in advanced, non-functional NETS of the lung, pancreas and gastrointestinal tract has been obtained in four clinical trials, named the 'RAD001 in advanced neuroendocrine tumors' (RADIANT) (Table 1). The first confirmatory phase II study (RADIANT-1) evaluated everolimus alone or in combination with long-acting octreotide in progressive chemo-resistant pNETs (Yao et al. 2010a). The first cohort (115 patients) received everolimus and the second cohort (45 patients) received longacting octreotide and everolimus. The overall RR plus stabilization was higher with the combination ( $84 \mathrm{vs} 77 \%$ ) as was mPFS (16.7 vs 9.7 months). Two other phase III trials with everolimus have been completed: RADIANT-2 studying the effect of everolimus and octreotide in advanced carcinoid tumors and the prospective RADIANT-3 in advanced pNETs (Yao et al. 2011).
The latter study compared best supportive care plus everolimus placebo in 410 patients. Two-hundred seven patients were included in the everolimus stratum and 203 in the placebo stratum. Everolimus prolonged mPFS from 4.6 to 11 months and demonstrated a $65 \%$ risk reduction for progression compared with placebo. The rather limited mPFS of about 11 months could be explained by acquired resistance to everolimus in the subset of patients that succumb of pNETs.

The most recent study is the RADIANT-4 trial (Yao et al. 2016). This randomized, double-blinded phase III trial included 302 patients with advanced, welldifferentiated NETs. In this study, patients received the best supportive care plus everolimus or placebo. Twohundred and five patients were included in the everolimus stratum and 97 patients in the placebo stratum. The mPFS was 11 months in the everolimus treated group and 3.9 months in the placebo group. Everolimus was associated with a 52\% RR for progression compared with placebo. Based upon these studies, everolimus has been approved in the treatment of advanced lung, pancreatic and gastrointestinal NET. However, no biomarker for sensitivity or resistance to everolimus treatment could be identified.

\section{Sunitinib therapy in neuroendocrine tumors}

\section{Mechanism of action of sunitinib}

Sunitinib malate is a small molecule competing with the ATP-binding domain of TKRs. Sunitinib blocks multiple components of the angiogenesis, including VEGFR-1/2/3, PDGFR- $\alpha / \beta$, fetal liver tyrosine kinase 3 (FLT-3), stem cell factor receptor (KIT), rearranged during transfection receptor (RET), colony-stimulating factor receptor type 1 receptor (CSF1R) and the glial cell line-derived neutrophic factor receptor (GDNF) (Fig. 4C; Mendel et al. 2003, Goodman et al. 2007, Wang et al. 2013).

Table 1 Summary of the RAD001 in advanced neuroendocrine tumors (RADIANT) trials.

\begin{tabular}{|c|c|c|c|c|}
\hline Study & Phase & Year & Cohort & Treatment \\
\hline RADIANT-1 & II & 2010 & 160 progressive, chemo-resistant pNETs & $\begin{array}{l}\text { Everolimus } \\
\text { Everolimus + Octreotide LAR }\end{array}$ \\
\hline RADIANT-2 & III & 2011 & 429 advanced carcinoid tumors & $\begin{array}{l}\text { Everolimus + Octreotide LAR } \\
\text { Placebo + Octreotide LAR }\end{array}$ \\
\hline RADIANT-3 & III & 2011 & 410 advanced pNETs & Everolimus vs placebo \\
\hline RADIANT-4 & III & 2016 & 302 advanced, well-differentiated NETs & Everolimus vs placebo \\
\hline Kulke et al. & II & 2008 & 107 advanced carcinoid and pNETs & Sunitinib \\
\hline SUN1111 & III & 2011 & 171 advanced, well-differentiated pNETs & Sunitinib vs placebo \\
\hline
\end{tabular}

\begin{tabular}{c}
\hline PFS \\
\hline 9.7 \\
16.7 \\
16.4 \\
11.3 \\
11 vs 4.6 \\
11 vs 3.9 \\
pNET: 7.7 \\
Carcinoid: 10.2 \\
11.4 vs 5.5 \\
\hline
\end{tabular}




\section{Clinical trials evaluating sunitinib safety and efficacy in neuroendocrine tumors}

The antitumoral effect of sunitinib was first demonstrated in NET in a phase II study in which sunitinib was administered to 107 patients with advanced, welldifferentiated NETs of various origin (Table 1). The objective response rate (ORR) was higher for patients with pNETs than for patients with carcinoid cancer (16.7 vs 2.4\%) (Kulke et al. 2008). In the SUN1111 phase III study, the efficacy of sunitinib was tested in 171 patients with advanced, well-differentiated pNETs, which showed PD during a 12-month period prior to initiation of the study (Raymond et al. 2011). The difference in mPFS between the treated group and the placebo group was 5.9 months (11.4 vs 5.5 months). In addition, an ORR of $9.3 \%$ was established in the treated group vs $0 \%$ in the placebo group (Raymond et al. 2011). Following the latter phase III trial, sunitinib was approved for treatment of unresectable or metastatic progressive well-differentiated pNET.

\section{Preclinical GEP-NET models}

Preclinical GEP-NET models have been used to elucidate resistance mechanisms to current therapies and to evaluate novel drugs. Several rapalogs and angiogenesis inhibitors were first evaluated in two-dimensional (2D) cell culture models, such as BON-1, QGP-1 and CM (Townsend et al. 1993, Arany et al. 1994, Zitzmann et al. 2010, Vandamme et al. 2016). In addition, these well-characterized in vitro models are used to investigate acquired therapy resistance (Passacantilli et al. 2014, Vandamme et al. 2016, Aristizabal Prada et al. 2018, Benten et al. 2018).

More recently, three-dimensional cultures or spheroids of neuroendocrine tumors cell lines have been established (Wang et al. 2018). These multicellular aggregates are more representative of the in vivo environment than monolayer cell culture. Importantly, significant differences in therapy response between classical 2D and spheroid culture of cells have been reported (Wang et al. 2018). To study GEP-NETs in vivo, different animal models have been developed. The most used rodent GEP-NET model relies on the promoter of rat insulin gene-2 (RIP), which drives the transgenic expression of simian virus 40 (SV40) large $\mathrm{T}$ antigen (Tag). In this RIP-Tag GEP-NET model, $\beta$ cell-specific, and exceptionally pancreatic polypeptide cell-specific, transgenic oncogene expression after activation of the insulin promotor drives cancerogenesis (Hanahan 1985, Power et al. 1987). The most frequently used lineages are RIP-Tag2 and RIP-Tag5 (Hanahan 1985, Adams et al. 1987, Onrust et al. 1996).
Much research has been done on the contribution of angiogenesis in the transition from hyperplasia to pNET, and as a potential treatment target in the RIP-Tag2 mice (Hanahan 1985, Folkman et al. 1989, Joyce et al. 2003, Casanovas et al. 2005). Transgenic RIP-Tag2 knockout mice have been used to elucidate the mechanisms of resistance to anti-angiogenetic VEGFR1 and VEGFR2 blocking antibodies in pNETs (Casanovas et al. 2005).

Patient-derived xenograft models (PDXs) have emerged as a preclinical tool, as these implanted human biopsy samples maintain the cellular and genetic context of the primary tumor (Daniel et al. 2009, Cottu et al. 2014, Ter Brugge et al. 2016). Since zebrafish (Danio rerio) embryos have highly conserved angiogenesis signaling compared to mammals, they often function as acceptor organism in the PDX approach (Hesselson et al. 2009, Rovira et al. 2011, Tehrani \& Lin 2011, Tobia et al. 2013). Vitale et al. established a novel angiogenesis NET assay by xenotransplantation of human TT (medullary thyroid cancer) and DMS79 (small-cell lung carcinoma secreting ACTH) cells into the subperidermal space of zebrafish embryos (Vitale et al. 2014). Gaudenzi et al. also successfully developed GEP-NET xenotransplantation models using cell lines from primary human tumor samples These experiments show that zebrafish can be a useful, high-throughput tool for patientderived GEP-NET compound sensitivity screening. Despite its usefulness to understand the mechanisms behind treatment resistance and to evaluate novel therapies, results obtained in models cannot always be translated to the clinic. Hence, development of novel cell line-, genetic and patient-derived (murine) models is needed for preclinical research into treatment resistance.

\section{Molecular mechanisms of resistance to rapalogs}

\section{Mutations in FKBP-12 and mTOR}

Rapalogs bind FKBP-12 and the latter complex inhibits mTORC1 via association with its FRB domain. Therefore, mutations in FKBP-12 or the FRB domain of mTOR have shown to induce resistance to rapalogs. Deletion of $R B P 1$ gene (mammalian FKBP-12 homologue) in Saccharomyces cerevisiae induced a rapamycin-resistant phenotype, while rescue by human FKBP-12 expression restored the treatment efficacy (Heitman et al. 1991, Koltin et al. 1991). Dumont et al. have demonstrated a reduced affinity of the FKBP-12-rapamycin complex for the FRB domain after introducing the $m T O R$ Ser2035>Ile2035 mutation (Dumont et al. 1995) (summarized in Table 2). (c) 2019 Society for Endocrinology Published by Bioscientifica Ltd. Printed in Great Britain 
Table 2 Summary of proposed mechanisms of resistance for rapalog and sunitinib monotherapy treatment in GEP-NET patients.

\begin{tabular}{ll}
\hline Treatment & Resistance mechanism \\
\cline { 2 - 3 } Rapalogs & GI3K/Akt/mTOR signaling mutations \\
& Activation PI3K/Akt/mTOR feedback \\
& Activation RAF/MEK/ERK signaling \\
& Activation PIM kinases \\
& Inactivation PP2A/activation PDK1 \\
& 4E-BP1/elF4E ratio \\
& Deregulation retinoblastoma \\
& Increased oxidative stress \\
& Anti-apoptotic signaling \\
& Pro-angiogenic tumor environment \\
& Epigenetic MYC activation \\
& Activation pro-angiogenic signaling \\
& Bone-marrow derived cells \\
Sunitinib & Increased pericyte coverage \\
& Lysosomal sequestration
\end{tabular}

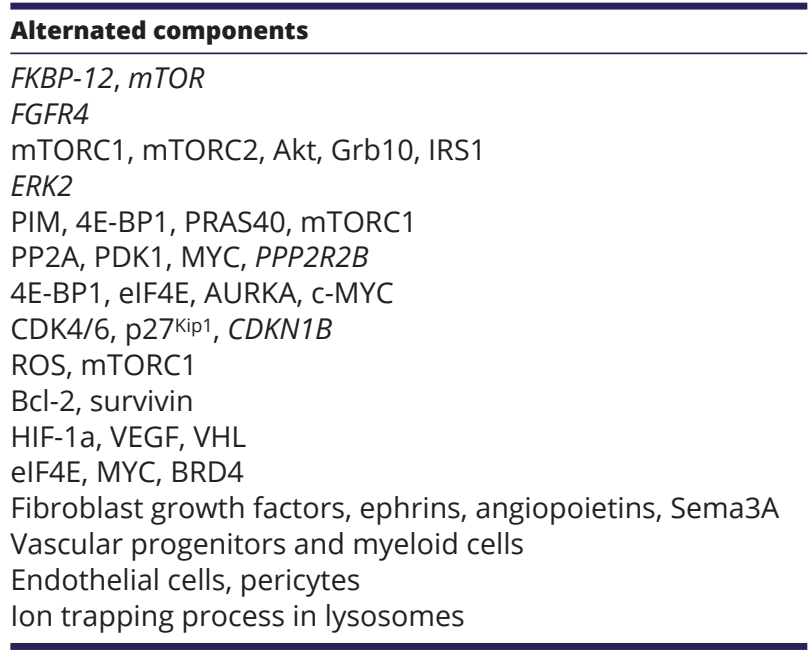

\section{Genetic alterations in growth signaling receptors}

In 2012, Serra et al. showed that a missense Gly388>Arg388 polymorphism in the fibroblast growth factor receptor 4 (FGFR4) was associated with more aggressive clinical behavior in patients with pNETs. These patients showed a reduction in everolimus treatment response. On the contrary, in 2016, Cros et al. evaluated the prognostic and predictive value of the FGFR4 Gly388>Arg388 mutation in everolimus efficacy in a NET cohort (Cros et al. 2016). This study did not confirm the mutations' prognostic nor its predictive value. The included immunochemistry staining did not show modulation of the PI3K/Akt/mTOR pathway activity.

\section{Activation of PI3K/Akt/mTOR pathway feedback loop}

A mTORC1-mTORC2 equilibrium exists, and mTORC1inhibition initiates phosphorylation of Akt via a shift toward mTORC2 signaling (Hay 2005). mTORC2 phosphorylates Akt at Ser473 and facilitates Thr308 phosphorylation by PDK1 (Sarbassov et al. 2005). This mTORC2-dependent increase of Akt activation is a known feedback mechanism that confers rapalog resistance (Wang et al. 2008). Furthermore, other mTORC2-independent mechanisms were found. mTORC1 can modulate the activity of mTORC2 via an existing negative feedback loop between mTORC1 and upstream PI3K signaling (Fig. 3A). This negative feedback loop is based on two well-known mechanisms. The first mechanism works via mTORC1-dependent phosphorylation and activation of growth factor receptor-bound protein 10 (Grb10). Grb10 activity will negatively modulate insulin-like growth factor $1 / 2$ receptors (IGF1R and IGF2R) by promoting their proteasomal degradation (Hsu et al. 2011, Yu et al. 2011). Secondly, S6K1/2 promotes the phosphorylationdependent degradation of insulin receptor substrate 1 (IRS1) (Harrington et al. 2004, Shah et al. 2004). As a consequence, silencing of mTORC1 will not inhibit upstream events via the feedback loop anymore. This might lead to increased Akt activation and diminished rapalog sensitivity (Sarbassov et al. 2005, Wang et al. 2008). Interestingly, a recent study demonstrated that GSK3, a downstream substrate of Akt, is constitutionally overactivated in everolimus-resistant GEP-NET cell lines, leading to downregulation of IRS1, thereby inhibiting the IRS1-mediated feedback loop (Aristizabal Prada et al. 2018).

\section{Activation of Raf/MEK/ERK pathway}

Numerous studies have established a causal link between mTOR inhibition and the activation of the Raf/MEK/ERK pathway. Carracedo et al. demonstrated an everolimus administration schedule-dependent increase of Raf/MEK/ERK signaling activation in patients with solid tumors in advanced diseases stages (Carracedo et al. 2008). In addition, mTOR inhibition in combination with a MEK1/2 inhibitor was synergistic for anti-proliferative effects in GEP-NET models (Valentino et al. 2014). In NET cell line models, gene expression analysis of the PI3K/Akt/mTOR and Raf/MEK/ERK pathway found ERK2 upregulated in induced rapalog resistance (Vandamme et al. 2016).

\section{Increased PIM kinase activity}

Pro-viral insertion in murine kinases (PIMs) are protooncogene serine/threonine-protein kinases located downstream of multiple oncogenic TKRs, including Janus 
kinase (JAK), Abelson (ABL) and FMS related tyrosine kinase 1 (Flt-3) (Wernig et al. 2008). Non-transformed hematopoietic cells can proliferate under rapamycinadded culture conditions. In this particular case, PIM kinases are required to confer rapamycin resistance (Hammerman et al. 2005). PIM enhances protein synthesis via the phosphorylation of 4E-BP1 and stimulates mTORC1 activity via phosphorylation of PRAS40, a suppressor of mTORC1 (Lilly \& Kraft 1997, Hammerman et al. 2005, Zhang et al. 2009).

\section{Inactivation of PP2A phosphatases and increased PDK1 activity}

Protein phosphatase 2A (PP2A) is a multiprotein serine/threonine phosphatase regulating cell growth, proliferation and survival (Chen et al. 2004, Wlodarchak \& Xing 2016). PP2A regulates PDK1 activity toward MYC phosphorylation. Epigenetic inactivation of PPP2R $2 B$ in colorectal cancer, encoding the $B 55 \beta$ regulatory subunit of the PP2A phosphatase, has been associated with rapamycin resistance (Tan et al. 2010). Following rapamycin treatment, dysfunctional PP2A induces PDK1dependent phosphorylation of MYC, and thus promotes cell proliferation (Tan et al. 2010).

\section{Modulation of 4E-BP1 and elF4E levels}

Deregulation of the downstream mTOR components eIF4E and 4E-BP1 have been correlated with cancer cell growth and drug resistance. Dilling et al. have detected a 10 -fold decrease of 4E-BP1 bound to eIF4E in rapamycinresistant Rh30 rhabdomyosarcoma clonal cells (Dilling et al. 2002). In the same study, colon carcinoma cell lines with intrinsic rapamycin resistance phenotype show low 4E-BP1:eIF4E ratios. Moreover, increased eIF4E expression drives tumorigenic cellular programs (Nathan et al. 1997). Recently, Aurora kinase A (AURKA) has been demonstrated to activate cap-dependent translation via eIF4E activating phosphorylation and upregulation of c-MYC protein levels. Overexpression of AURKA has been observed in several cancer types and is associated with everolimus resistance in gastrointestinal adenocarcinoma cell lines (Katsha et al. 2017).

\section{Dysregulation of the retinoblastoma pathway}

The retinoblastoma pathway strictly controls the cell cycle $G_{1}-S$ phase. Physiologically, p27Kip1, a cyclindependent kinase inhibitor, inhibits cyclin D1 - CDK4/6 complex. This inhibition prevents phosphorylation of retinoblastoma (RB) and its dissociation from transcription factors implicated in the $\mathrm{G}_{1}-\mathrm{S}$ progression. Luo et al. have shown that rapamycin prevents the downregulation of p27Kip1. In their long-term drug culture study, rapamycin-resistant murine BC3H1 cells exhibited an intact S6K signaling, while p27 protein levels were decreased by increased ubiquitinindependent degradation (Luo et al. 1996).

\section{Increase in oxidative stress}

Increased oxidative stress is another mechanism of resistance to rapalogs (Neklesa \& Davis 2008). In yeast strains with elevated reactive-oxygen species (ROS), specific mTORC1 modifications occur that prevent binding of the FKBP-12-rapamycin complex (Neklesa \& Davis 2008). Elevated production of ROS is one of the hallmark features for cancer (Chio \& Tuveson 2017). Considering this mechanism of action, high levels of ROS may confer resistance to rapalogs in various clinical samples.

\section{Stimulation of anti-apoptotic signals}

Several studies report that rapalogs induce apoptosis via activation of the mitochondrial apoptotic pathway (Hosoi et al. 1999, Wang 1999, Majumder et al. 2004). One of the regulators of this apoptotic pathway is the anti-apoptotic protein Bcl-2. Deregulation of the apoptotic pathway via elevated expression of $\mathrm{Bcl}-2$ in NET has highlighted the importance of this cascade (Wang 1999). Additionally, a preclinical study with induced Bcl-2 expression under rapalog treatment showed inhibition of the PI3K/Akt/mTOR pathway and decreased cell proliferation. Notwithstanding the successful mTOR inhibition, cells with Bcl-2 induced expression show increased inhibition of apoptosis and caused a partial rapalog resistance phenotype (Majumder et al. 2004). Another key regulator is the anti-apoptotic protein survivin. Elevated expression of nuclear survivin is correlated with an increased progression in GEP-NETs (Grabowski et al. 2005).

\section{Stimulation of pro-autophagy signals}

The role of autophagy in cancer is dependent on the cellular context. Induction or suppression of autophagy may exert therapeutic effects by its dual role in either 
promoting cell survival or death (Rubinsztein et al. 2007). mTORC1 is an inhibitor of autophagy processes (Saxton \& Sabatini 2017). Hence, rapalogs induce autophagy and help to maintain the cancer cell survival. Similarly, it promotes cell proliferation under nutrient-poor microenvironments via increased catabolism of endocytosed proteins (Palm et al. 2015). In Mantle cell lymphoma, accumulation of autophagic vacuoles confers to rapalog resistance. The lack of efficacy can be restored by the inhibition of the autolysosome formation by hydroxychloroquine, a potent autophagy inhibitor (Rosich et al. 2013).

\section{Pro-angiogenic tumor environment}

Pinato et al. demonstrated via immunostaining of HIF-1 $\alpha$, VEGF-A and Carbonic anhydrases IX (Ca-IX) an important contribution of an angiogenic expression signature in GEP-NETs (Pinato et al. 2014). These GEP-NETs are highly vascularized by significant upregulation of HIF- $1 \alpha$. The activation of HIF- $1 \alpha$ is driven by genetic inactivation of the VHL protein and the stimulating hypoxic conditions that are typically present in GEP-NET cellular environments. Rapalogs have proven anti-angiogenic and vascular cell proliferation characteristics in tumor environments (Lane et al. 2009). One of the proposed mechanisms is the downregulation of HIF-1 $\alpha$ expression under treatment. Rapalog resistance might emerge via the upregulation of pro-angiogenic factors via a mTOR-independent cascade or, re-expression or re-activation of HIF-1 $\alpha$ (Majumder et al. 2004, Vandamme et al. 2016, Antonuzzo et al. 2017).

\section{Epigenetic induction of MYC signatures}

Matsumoto et al. indicated an important contribution of MYC to everolimus resistance in the small-cell lung cancer SBC5 cell line. Long-term everolimus treated and resistant SBC5 cells show upregulation of eIF4E, but display restoration of everolimus sensitivity after silencing MYC gene expression (Matsumoto et al. 2015). This suggests that MYC directly activates eIF4E by phosphorylation in an mTOR-independent signaling. Others have demonstrated increased MYC protein levels and enrichment of MYC signatures in everolimus-resistant ER+ breast cancer cells (Bihani et al. 2015). They show with immunoprecipitation assays that the MYC upregulation is mediated by an increase of bromodomain-containing protein 4 (BRD4) levels, an epigenetic reader involved in acetylation of lysine residues, and recruiter of chromatin modifiers and remodeling enzymes (Filippakopoulos \& Knapp 2014).

\section{Molecular mechanisms of resistance to sunitinib}

\section{Hypoxia-induced activation of alternative pro-angiogenic signaling and metastatic dissemination}

Casanovas et al. have used the pancreatic neuroendocrine Rip1-Tag2 mouse model to elucidate the escape mechanism to anti-angiogenic therapy (Casanovas et al. 2005). Under prolonged treatment they reported that initial tumor growth inhibition was followed by tumor progression. Upon progression, the tumors showed a more invasive behavior. They demonstrated, while maintained under continuous anti-angiogenic treatment, that the tissues still display a high-density of microvessels. Since the vascularization density of the tumor tissue was unaffected by treatment, it was suggested that the tumor developed resistance via the activation of VEGFindependent cascades, including fibroblast growth factors (FGF), ephrins and angiopoietins. Latter proangiogenic factors were upregulated in the tumor cells. Noteworthy, expression of semaphorin 3A (Sema3A), a known component of the FGF-induced angiogenesis, counteracted the sunitinib-induced activation of HIF-1 $\alpha$ in pNET Rip-Tag2 mice (Maione et al. 2012). In this study, Sema3A expression reduced the likelihood for metastatic dissemination (summarized in Table 2).

\section{Recruitment of bone-marrow derived cells}

Several bone-marrow derived cells are recruited as consequence of the local hypoxic tumor environment (Pàez-Ribes et al. 2009, Azam et al. 2010). The local hypoxic environment is enhanced by a combination of the expansion of the tumor cells and by the treatment of anti-angiogenic, including sunitinib. The recruited bonemarrow cells, including vascular progenitors and myeloid cells, promote locally the formation of new microvessels, and thereby these cells maintain the high-demanded blood supply of tumoral tissue (Azam et al. 2010).

\section{Increase of pericyte coverage}

Pericytes are wrapped around microvessels and have a supportive function in the microvasculature (Allt \& Lawrenson 2001). In addition, these cells interact with the endothelial cells' proliferation, migration and stabilization. Endothelial cells might stimulate the pericyte population around the microvessels via several signaling cascades, including PDGF (Allt \& Lawrenson 2001). (c) 2019 Society for Endocrinology Published by Bioscientifica Ltd. Printed in Great Britain 
Pericytes gained attention as they are an important cellular regulator in tumor angiogenesis (Sims 1986). Pathological activation of pericytes induces the formation of abnormal complicated microvessel networks embedding the tumor cells (Taylor et al. 2015). Cao et al. reported that increased pericyte-generated microvessel formation confers to antiangiogenic treatment resistance in clear-cell renal cell carcinoma (Cao et al. 2013). Paradoxically, a lowered pericyte population not only impairs the tumor vascular network, and consequently inhibits tumor growth, but it also increases the likelihood for metastatic dissemination (Cooke et al. 2012).

\section{Lysosomal sunitinib sequestration}

The hydrophobic weak base characteristics of sunitinib results in its storage in the intracellular acidic lysosomes via ion trapping processes (Logan et al. 2013). The sequestration of sunitinib has been reported first in sunitinib-resistant patients with clear-cell renal cell carcinoma (Gotink et al. 2015). More recently, this resistance mechanism has been described in pNET (Wiedmer et al. 2017). Combinational treatment of sunitinib and the autophagy inhibitor chloroquine, reduced cell viability of pNET cells and reduced tumor burden in Rip1-Tag2 pNET mice. Chloroquine induces lysosomal membrane permeabilization and subsequent release of sunitinib.

\section{Overcoming resistance}

\section{Novel PI3K/Akt/mTOR inhibitors}

\section{mTOR kinase inhibitors (TORKis)}

Next-generation mTOR inhibitors have been developed to overcome therapy resistance mechanisms or reduce adverse events. Inhibitors that illicit dual inhibition of the catalytic activity of mTORC1 and mTORC2 may overcome the negative feedback loop via S6K1/2 and mTORC2 and are therefore attractive inhibitors. The second-generation of mTOR inhibitors, referred as small-molecule mTOR kinase inhibitors (TORKis), inhibit the kinase activity of mTORC1 and mTORC2 in an FKBP-12-independent mechanism of action by competitively binding the ATPbinding mTOR kinase pocket (Fig. 3C; Feldman et al. 2009, Thoreen et al. 2009, Yu et al. 2009). One of the first in-depth investigated TORKi is PP242 (Feldman et al. 2009). Feldman et al. demonstrated in vitro and in vivo evidence that PP242 directly binds the ATP site of both mTOR complexes. Drug treatment disrupts the feedback loop of mTORC2 by reducing mTORC2-dependent phosphorylation of Akt at Ser437 (Feldman et al. 2009). As a result, PP242 negatively affects cap-dependent translation under rapamycin-resistant conditions via suppressing mTORC1-dependent phosphorylation of 4E-BP1 at Thr37 and Thr46 (Feldman et al. 2009).

Various TORKis have been developed, including AZD2014 and OSI-027, and their clinical relevance was assessed in clinical trials. AZD2014 efficacy has been proven to be inferior to everolimus in a phase II study including metastatic renal cell carcinoma with mPFS 1.8 and 4.6 months, in AZD2014 and everolimus stratum respectively (Powles et al. 2016). In our rapalog resistance model, we have shown that AZD2014 is a potent TORKIs in overcoming everolimus resistance in pNETs (Vandamme et al. 2016). AZD2014 effectively reduces cell proliferation in resistant BON-1 and QGP-1 cells in concentrations reachable in patients (Basu et al. 2015).

A dose-finding phase I trial evaluating OSI-027 in advanced solid cancers demonstrated that the effective concentrations of the drug were above the tolerable doses (Mateo et al. 2016). One of the major adverse effects was the acute onset of renal impairment within few days of treatment. For this reason, the clinical development has been discontinued. Nonetheless, OSI-027 showed promising results in a resistant BON-1 cell line, whereas it had only a limited efficacy in a resistant QGP-1 cell line (Vandamme et al. 2016).

Additionally, TORKis could circumvent the rapalog resistance in patients with $F K B P-12$ or $m T O R$ FRB domain mutations, since TORKis have an FKBP-12-independent mechanism of action and directly inhibit mTOR's kinase domain.

\section{Dual PI3K and mTOR inhibitors}

The PI3K kinase family includes three classes (I-III) that differ in structure and substrate specificity. Several studies showed the involvement of the catalytic domain of the class IA PI3K p110 subunits in various tumor types (Liu et al. 2009, Fruman \& Rommel 2014). Most of the therapeutic PI3K-inhibitors target all class IA PI3K p110 isoforms. Incidentally, isoform specificity has been reported for some of the compounds (Knight et al. 2006, Liu et al. 2009). Most ATP-competitive class IA PI3K-inhibitors, including BEZ235, do not only block PI3K, they also inhibit mTORC1 and mTORC2 kinase activity, due to catalytic cleft homology (Fig. 3D; Engelman et al. 2006). These inhibitors prevent unwanted feedback activation of PI3K signaling and the mTORC2dependent Akt activation via phosphorylation. While this broad inhibitory activity is beneficial from a therapeutic 
point of view, it also causes serious side effects limiting the clinical applicability. BEZ235 showed promise in multiple preclinical studies. High efficiency in inhibiting the PI3K-Akt-mTOR pathway and cell proliferation has been ascribed to its combined PI3K, mTORC1 and mTORC2 inhibition (Maira et al. 2008, Passacantilli et al. 2014). Vandamme et al. demonstrated that BEZ235 is able to overcome in vitro acquired rapalog resistance (Vandamme et al. 2016). In addition, Passacantilli et al. showed by using in vitro $\mathrm{pNET}$ assays that $\mathrm{mTORC} 1$ activity was inhibited at $1-10 \mathrm{nM}$, while for PI3K and mTORC2 kinase activity inhibition higher doses of 100-250 nM were needed (Passacantilli et al. 2014). The latter study evaluated the combination of everolimus alongside with BEZ235. In aggregate, these studies demonstrate a strong synergic effect on cell proliferation in several cancers including pNETs, even with doses of everolimus and BEZ235 that had limited efficacy in monotherapy (Xu et al. 2011, Nyfeler et al. 2012, Passacantilli et al. 2014).

Despite the promising preclinical results, two phase II trials testing BEZ235 in pNETs were terminated prematurely due to limited efficacy and a challenging tolerability profile compared to everolimus (Fazio et al. 2016, Salazar et al. 2017). The first phase II trial evaluating BEZ235 in patients with everolimus-resistant pNETs never reached stage 2 of the trial, which would have been triggered by a 16-week PFS rate of $>60 \%$ in stage 1 . The lower than expected PFS is due to the high rate ( $72.7 \%$ of the patients) of treatment-related grade 3 and 4 side effects (Fazio et al. 2016). In another phase II study evaluating everolimus vs BEZ235 in patients with everolimus-sensitive pNETs, BEZ235 treatment showed a limited degree of efficacy with a median PFS of 8.2 months compared to that of the everolimus treated group with a median PFS of 10.8 months (Salazar et al. 2017). The lack of efficacy may be described to the poorer tolerability of BEZ235; the adverse effects were twice as frequent in the BEZ235 arm of the study (Salazar et al. 2017). Although further clinical trials evaluating BEZ235 are halted, other ATP-competitive dual inhibitors could be considered if they show less adverse effects.

Nölting et al. evaluated the selective PI3Kp110 $\alpha$ inhibitor BYL719 in BON-1, QGP-1 and H727 NET cell lines (Nölting et al. 2017). BYL719 exposure resulted in an upregulation of $\mathrm{p} 27$, and consequently resulted in an increase of $G_{0} / G_{1}$ cell cycle arrest. Others reported marginal effects of BYL719 on the pNET cell proliferation, despite its ability to suppress PI3K-dependent phosphorylation of Akt (Passacantilli et al. 2014). Nevertheless, Nölting et al. showed that combination of everolimus and BYL719 had synergistic effects on cell proliferation (Nölting et al. 2017). In addition, combination of BYL719 with everolimus re-established everolimus sensitivity in a resistant cell line model (Aristizabal Prada et al. 2018). Recently, Chamberlain et al. developed a PDX model in zebrafish where they evaluated everolimus and the second-generation mTOR inhibitor sapanisertib (INK128) (Chamberlain et al. 2018). They show that sapanisertib overcomes everolimus resistance. Sapanisertib is currently under evaluation in a phase II trial of rapalog-resistant pNET (NCT02893930, clinicaltrial.gov).

\section{Third-generation of mTOR inhibitors}

The third-generation mTOR inhibitors exploit both the ATP- and the FRB-binding sites of mTOR (Fig. 3C). Included in this new category of compounds is RapaLink-1, in essence a TORKi linked to rapamycin (RodrikOutmezguine et al. 2016). RapaLink-1 binds FKBP-12 via the rapamycin molecule, which enables accumulation of the inhibitory complex in the cell. Recently, Fan et al. have reported a significant increase in efficacy of RapaLink-1 in an in vitro study of glioblastoma as compared with first- and second-generation mTOR inhibitors (Fan et al. 2017). RapaLink-1 suppresses mTORC2-dependent phosphorylation of Akt at Ser473 more effectively than rapamycin. Above all, this novel inhibitor has a longer cellular residence time compared to the TORKis. Finally, they confirmed the beneficial efficacy of RapaLink-1 in intracranial glioblastoma xenografts.

\section{Novel angiogenesis inhibitors}

Next to sunitinib, two types of anti-angiogenic compounds have been assessed for their efficacy in patients with advanced NETs: small molecules competing with the tyrosine kinase receptor domain of the VEGF receptor, such as sorafenib, pazopanib and vatalanib (Chan et al. 2013, Wagle et al. 2014, Yoo et al. 2017); and monoclonal antibody against VEGF, such as bevacizumab (Yao et al. 2010b). Most studies evaluate bevacizumab in combination with a chemotherapy backbone. A phase II study combining bevacizumab with temozolomide in 34 patients with advanced neuroendocrine tumors showed mOS of 33.1 months with an acceptable toxicity profile (Chan et al. 2012). Bevacuzimab in combination with capecitabine showed a mPFS of 32.4 months and an 2-year-survival rate of $85 \%$ in a single-arm phase II trial including 49 patients with advanced NET (Mitry et al. 2014). One phase III trial randomized between octreotide LAR, a somatostatin analog, plus bevacizumab and octreotide LAR plus interferon-alpha-2b (IFNa-2b), 
an immune-stimulating drug. Of the 427 patients enrolled, 214 received bevacizumab, while 213 patients received IFNa-2b. The median PFS by central review was 16.6 months in the bevacizumab arm and was 15.4 months in the IFN arm, resulting in an mPFS difference which was not statistically significant (Yao et al. 2017). After initial studies demonstrating possible efficacy of sorafenib in NET, a phase II study combining bevacizumab with sorafenib recruited 44 patients with advanced NETs. Despite a promising mPFS of 12.4 months, toxicity was unacceptably high with grade 3-4 toxicity in up to $63 \%$ of included patients, effectively prohibiting clinical use (Castellano et al. 2013).

\section{Targeted therapy combinations}

\section{Combining everolimus and sunitinib}

The cross-talk between PI3K/Akt/mTOR and VEGF signaling in NETs provides rationale for the combination of everolimus and sunitinib in NETs (Villaume et al. 2010, Karar \& Maity 2011). Yoo et al. evaluated retrospectively the efficacy and safety of everolimus and sunitinib in 44 patients with GEPNETs (Yoo et al. 2017). The PFS in the pNET patient cohort treated with combined everolimus and sunitinib ranged was respectively 16.6 months and 8.0 months in these two studies. However, toxicity of the combination treatment was significantly increased. Hence, sequential treatment might be a better approach. A retrospective study in 31 pNET patients, showed that sequential treatment was welltolerated (Angelousi et al. 2017). No significant difference in the mPFS was found between patients receiving first everolimus followed by sunitinib (mPFS 36.5 months) and patients in the sunitinib to everolimus group (mPFS 31.6 months) (Angelousi et al. 2017).

\section{Co-targeting vascular signaling}

Next to combining sunitinib and everolimus, different other angiogenesis inhibitors have been combined with everolimus in clinical trials. Chan et al. showed in a phase I trial of patients with advanced NET that the combination of everolimus and sorafenib is active in $62 \%$ of the patients, as these patients had some degree of tumor shrinkage. However, toxicity might limit the use of this drug combination. A more well-tolerated combination is everolimus plus bevacizumab. A large phase II trial evaluated the combination everolimus and bevacizumab in 150 patients with advanced or metastatic pNETs (Kulke et al. 2016). The combination was associated with a modest increase in PFS of 16.7 months vs 14 months compared to the everolimus-only stratum. While a significant higher response rate (31\%) in the combination was observed compared to everolimus alone (12\%). However, substantial adverse events were reported in the patients treated within the drug combination group, limiting its clinical use.

As sunitinib and bevacizumab block different angiogenic pathways, a possible therapeutic approach could be to combine both to increase clinical efficacy. However, two phase I exploratory studies in different malignancies, showed unacceptable hematologic toxicity, despite an increase in response rates in comparison to monotherapy (Rini et al. 2009, Capozzi et al. 2016).

Wang et al. evaluated the VEGFR-inhibitors sunitinib and axitinib in neuroendocrine H272 cell line spheroids and monolayer culture. A synergistic effect of combined treatment with axitinib and sunitinib was seen in comparison with monotherapy. However, synergistic efficacy was less pronounced in spheroids, warranting caution in translating these results to the clinic (Wang et al. 2018).

\section{Co-targeting epidermal growth factor receptors}

Another treatment modality involves dual targeting of mTOR kinase activity and tyrosine kinase receptor EGFR. Chiu et al. demonstrated in a preclinical model of pNET that combination therapy of everolimus and the EGFR inhibitor erlotinib was efficacious (Chiu et al. 2010). Strikingly, the combination prevented development of acquired resistant to everolimus. In addition, the combination of everolimus and erlotinib has shown promising in large-cell and bronchial NETs (Bago-Horvath et al. 2012). The combination resulted in higher antitumor activities than monotherapy alone via a synergistic apoptosis activity. In particular, the combined therapy induced a synergistic downregulation of the phosphorylation levels of mTOR, S6K1/2 and Akt.

\section{Co-targeting epigenetic modulation}

Epigenetic modifications seem to be involved in therapy resistance through transcriptional silencing of target components or activation of rescue pathways (Berdasco \& Esteller 2010, Kelly et al. 2010, Wilting \& Dannenberg 2012, Hervouet et al. 2013). In prostate cancer cell lines, the histone deacetylase (HDAC) inhibitor valproic acid has been shown to overcome resistance to temsirolimus, a rapalog (Makarević et al. 2018). Moreover, valproic acid acetylates histone variants $\mathrm{H} 3$ and $\mathrm{H} 4$ in temsirolimusresistant bladder cancer and in everolimus-resistant renal cancer cells (Juengel et al. 2012, 2014, 2017). Finally, valproic acid increases rapalog sensitivity via regulation 
of the CDK2/cyclin A cell cycle axis (Juengel et al. 2012, 2014). These results have led to multiple phase I studies with (pan-) HDAC inhibitors panobinostat and vorinostat in combination with rapalogs in cancer, showing promising results (Strickler et al. 2012, Oki et al. 2013, Zibelman et al. 2015, Earwaker et al. 2018).

Likewise, demethylating compounds such as 5-aza2-deoxycytidine were effective in combination with everolimus in medullary thyroid cancer (Vitale et al. 2017). The synergistic effect has been linked to apoptosis induction through $\mathrm{Bax}$ and $\mathrm{Bcl}-2$, two downstream effectors of mTOR (Jin et al. 2007, Dimaras \& Gallie 2008, Küchler et al. 2011, Yang et al. 2015). Hence, targeting epigenetic changes in GEP-NET could be an interesting strategy to overcome everolimus resistance.

\section{Co-targeting immune surveillance}

Currently, another promising field in drug development is that of immunotherapy. A major breakthrough was the development of immune checkpoint inhibitors that prevent the interaction between the programmed death ligand-1 (PD-L1) of tumor cells and programmed cell death-1 (PD1) or cytotoxic T-lymphocyte-associated protein-4 (CTLA4) of T-cells. Tumor cells might remain undetected by immune surveillance by production of antigens that inhibit T-cells. Hence, these inhibitors that target the PD-L1 prevent immune escape of the cancer cells. A myriad of antibodies, such avelumab (anti-PD-L1), pembrolizumab, nivolumab, JS001, or PDR001 (anti-PD1) or ipilimumab (anti-CTLA4) showed promising in different tumor types, including melanoma, renal cell, urothelial, and non-small-cell lung carcinoma (Xu-Monette et al. 2017). Spranger and Gajeweski described a clear role of PTEN loss to evade the immune surveillance. Loss of PTEN, frequently detected in NETs and integral member of PI3K/Akt/mTOR, supports the idea of combining PI3K/Akt/mTOR inhibitors and immunotherapy in NETs. Hence, this therapy combination is being evaluated in an ongoing phase I trial in solid cancers (NCT02646748, clinicaltrial.gov).

\section{Conclusions}

The approved targeted therapies in NET include everolimus and sunitinib. However, treatment resistance poses a clinical challenge. Preclinical research allowed for a better understanding of the resistance mechanisms and has led to the introduction of novel compounds into clinical trials. In addition, combination therapy seems a promising approach to overcome everolimus and sunitinib resistance. As a matter of fact, these novel treatment strategies may be associated with a stronger anti-proliferative capacity than everolimus and sunitinib monotherapy. However, the associated increase in side effects underscore the need for a proper selection of patients likely to benefit the most. Hence, an individualized approach to treatment of NET patients remains crucial.

\section{Declaration of interest}

Timon Vandamme: advisory role and speakers' fees for Ipsen and Novartis. Marc Peeters: advisory role and speakers' fees for Ipsen and Novartis. The other authors declare that there is no conflict of interest that could be perceived as prejudicing the impartiality of this review.

\section{Funding}

This work was supported by the Flemish Agency of Scientifc Research (FWO grant G.0327.13N) and Kom op tegen Kanker (Stand up to Cancer, the Flemish Cancer Society).

\section{References}

Adams TE, Alpert S \& Hanahan D 1987 Non-tolerance and autoantibodies to a transgenic self antigen expressed in pancreatic $\beta$ cells. Nature 325 223-228. (https://doi.org/10.1038/325223a0)

Alitalo R, Aprelikova O, Korhonen J, Kaipainen A, Alitalo K \& Pertovaara L 1992 FLT4 receptor tyrosine kinase contains seven immunoglobulin-like loops and is expressed in multiple human tissues and cell lines. Cancer Research 52 5738-5743.

Allt G \& Lawrenson JG 2001 Pericytes: cell biology and pathology. Cells Tissues Organs 169 1-11. (https://doi.org/10.1159/000047855)

Angelousi A, Kamp K, Kaltsatou M, O’Toole D, Kaltsas G \& De Herder W 2017 Sequential everolimus and sunitinib treatment in pancreatic metastatic well-differentiated neuroendocrine tumours resistant to prior treatments. Neuroendocrinology 105 394-402. (https://doi. org/10.1159/000456035)

Antonuzzo L, Del Re M, Barucca V, Spada F, Meoni G, Restante G, Danesi R, Di Costanzo F \& Fazio N 2017 Critical focus on mechanisms of resistance and toxicity of m-TOR inhibitors in pancreatic neuroendocrine tumors. Cancer Treatment Reviews $\mathbf{5 7}$ 28-35. (https://doi.org/10.1016/j.ctrv.2017.05.001)

Arany I, Rady P, Evers BM, Tyring SK \& Townsend CM 1994 Analysis of multiple molecular changes in human endocrine tumours. Surgical Oncology 3 153-159. (https://doi.org/10.1016/0960-7404(94)90044-2)

Arias E, Koga H, Diaz A, Mocholi E, Patel B \& Cuervo AM 2015 Lysosomal mTORC2/PHLPP1/Akt regulate chaperone-mediated autophagy. Molecular Cell 59 270-284. (https://doi.org/10.1016/j. molcel.2015.05.030)

Aristizabal Prada ET, Spöttl G, Maurer J, Lauseker M, Koziolek EJ, Schrader J, Grossman A, Pacak K, Beuschlein F, Auernhammer CJ, et al. 2018 The role of GSK3 and its reversal with GSK3 antagonism in everolimus resistance. Endocrine-Related Cancer 25 893-908. (https://doi.org/10.1530/ERC-18-0159)

Azam F, Mehta S \& Harris AL 2010 Mechanisms of resistance to antiangiogenesis therapy. European Journal of Cancer 46 1323-1332. (https://doi.org/10.1016/j.ejca.2010.02.020)

Bago-Horvath Z, Sieghart W, Grusch M, Lackner A, Hayden H, Pirker C, Komina O, Wẹsierska-Ga̧dek J, Haitel A, Filipits M, et al. 2012 Synergistic effects of erlotinib and everolimus on bronchial carcinoids and large-cell neuroendocrine carcinomas with activated EGFR/AKT/mTOR pathway. Neuroendocrinology 96 228-237. (https:// doi.org/10.1159/000337257) 
Baker H, Sidorowicz A, Sehgal SN \& Vézina C 1978 Rapamycin (AY$22,989)$, a new antifungal antibiotic. III. In vitro and in vivo evaluation. Journal of Antibiotics 31 539-545. (https://doi. org/10.7164/antibiotics.31.539)

Basu B, Dean E, Puglisi M, Greystoke A, Ong M, Burke W, Cavallin M, Bigley G, Womack C, Harrington EA, et al. 2015 First-in-human pharmacokinetic and pharmacodynamic study of the dual m-TORC 1/2 inhibitor AZD2014. Clinical Cancer Research 21 3412-3419. (https://doi.org/10.1158/1078-0432.CCR-14-2422)

Battegay EJ, Rupp J, Iruela-Arispe L, Sage EH \& Pech M 1994 PDGF-BB modulates endothelial proliferation and angiogenesis in vitro via PDGF $\beta$-receptors. Journal of Cell Biology 125 917-928. (https://doi. org/10.1083/jcb.125.4.917)

Benten D, Behrang Y, Unrau L, Weissmann V, Wolters-Eisfeld G, BurdakRothkamm S, Stahl FR, Anlauf M, Grabowski P, Möbs M, et al. 2018 Establishment of the first well-differentiated human pancreatic neuroendocrine tumor model. Molecular Cancer Research 16 496-507. (https://doi.org/10.1158/1541-7786.MCR-17-0163)

Berdasco M \& Esteller M 2010 Aberrant epigenetic landscape in cancer: how cellular identity goes awry. Developmental Cell 19 698-711. (https://doi.org/10.1016/j.devcel.2010.10.005)

Bihani T, Ezell SA, Ladd B, Grosskurth SE, Mazzola AM, Pietras M, Reimer C, Zinda M, Fawell S \& D'Cruz CM 2015 Resistance to everolimus driven by epigenetic regulation of MYC in ER+ breast cancers. Oncotarget 6 2407-2420. (https://doi.org/10.18632/ oncotarget.2964)

Boons G, Vandamme T, Peeters M, Beyens M, Driessen A, Janssens K, Zwaenepoel K, Roeyen G, Van Camp G \& Op de Beeck K 2018 Cellfree DNA from metastatic pancreatic neuroendocrine tumor patients contains tumor-specific mutations and copy number variations. Frontiers in Oncology 8 467. (https://doi.org/10.3389/fonc.2018.00467)

Ter Brugge P, Kristel P, Van Der Burg E, Boon U, De Maaker M, Lips E, Mulder L, De Ruiter J, Moutinho C, Gevensleben H, et al. 2016 Mechanisms of therapy resistance in patient-derived xenograft models of brca1-deficient breast cancer. Journal of the National Cancer Institute 108 djw148. (https://doi.org/10.1093/jnci/djw148)

Brunet A, Bonni A, Zigmond MJ, Lin MZ, Juo P, Hu LS, Anderson MJ, Arden KC, Blenis J \& Greenberg ME 1999 Akt promotes cell survival by phosphorylating and inhibiting a forkhead transcription factor. Cell 96 857-868. (https://doi.org/10.1016/ S0092-8674(00)80595-4)

Cao Z, Shang B, Zhang G, Miele L, Sarkar FH, Wang Z \& Zhou Q 2013 Tumor cell-mediated neovascularization and lymphangiogenesis contrive tumor progression and cancer metastasis. Biochimica et Biophysica Acta 1836 273-286. (https://doi.org/10.1016/j. bbcan.2013.08.001)

Capdevila J \& Tabernero J 2011 A shining light in the darkness for the treatment of pancreatic neuroendocrine tumors. Cancer Discovery 1 213-221. (https://doi.org/10.1158/2159-8290.CD-11-0151)

Capozzi M, von Arx C, De Divitiis C, Ottaiano A, Tatangelo F, Romano GM \& Tafuto S 2016 Antiangiogenic therapy in pancreatic neuroendocrine tumors. Anticancer Research 36 5025-5030. (https:// doi.org/10.21873/anticanres.11071)

Carracedo A, Ma L, Teruya-Feldstein J, Rojo F, Salmena L, Alimonti A, Egia A, Sasaki AT, Thomas G, Kozma SC, et al. 2008 Inhibition of mTORC1 leads to MAPK pathway activation through a PI3Kdependent feedback loop in human cancer. Journal of Clinical Investigation 118 3065-3074. (https://doi.org/10.1172/JCI34739)

Casanovas O, Hicklin DJ, Bergers G \& Hanahan D 2005 Drug resistance by evasion of antiangiogenic targeting of VEGF signaling in latestage pancreatic islet tumors. Cancer Cell 8 299-309. (https://doi. org/10.1016/j.ccr.2005.09.005)

Castellano D, Capdevila J, Sastre J, Alonso V, Llanos M, GarcíaCarbonero R, Manzano Mozo JL, Sevilla I, Durán I \& Salazar R 2013 Sorafenib and bevacizumab combination targeted therapy in advanced neuroendocrine tumour: a phase II study of Spanish
Neuroendocrine Tumour Group (GETNE0801). European Journal of Cancer 49 3780-3787. (https://doi.org/10.1016/j.ejca.2013.06.042)

Chamberlain CE, German MS, Yang K, Wang J, VanBrocklin H, Regan M, Shokat KM, Ducker GS, Kim GE, Hann B, et al. 2018 A patient-derived xenograft model of pancreatic neuroendocrine tumors identifies sapanisertib as a possible new treatment for everolimus-resistant tumors. Molecular Cancer Therapeutics 17 2702-2709. (https://doi.org/10.1158/1535-7163.MCT-17-1204)

Chan JA, Stuart K, Earle CC, Clark JW, Bhargava P, Miksad R, Blaszkowsky L, Enzinger PC, Meyerhardt JA, Zheng H, et al. 2012 Prospective study of bevacizumab plus temozolomide in patients with advanced neuroendocrine tumors. Journal of Clinical Oncology 30 2963-2968. (https://doi.org/10.1200/JCO.2011.40.3147)

Chan JA, Mayer RJ, Jackson N, Malinowski P, Regan E \& Kulke MH 2013 Phase I study of sorafenib in combination with everolimus (RAD001) in patients with advanced neuroendocrine tumors. Cancer Chemotherapy and Pharmacology 71 1241-1246. (https://doi. org/10.1007/s00280-013-2118-9)

Chen J, Zheng XF, Brown EJ \& Schreiber SL 1995 Identification of an 11-kDa FKBP12-rapamycin-binding domain within the 289-kDa FKBP12-rapamycin-associated protein and characterization of a critical serine residue. PNAS 92 4947-4951. (https://doi.org/10.1073/ pnas.92.11.4947)

Chen W, Possemato R, Campbell KT, Plattner CA, Pallas DC \& Hahn WC 2004 Identification of specific PP2A complexes involved in human cell transformation. Cancer Cell 5 127-136. (https://doi. org/10.1016/S1535-6108(04)00026-1)

Chio IIC \& Tuveson DA 2017 ROS in cancer: the burning question. Trends in Molecular Medicine 23 411-429. (https://doi.org/10.1016/j. molmed.2017.03.004)

Chiu CW, Nozawa H \& Hanahan D 2010 Survival benefit with proapoptotic molecular and pathologic responses from dual targeting of mammalian target of rapamycin and epidermal growth factor receptor in a preclinical model of pancreatic neuroendocrine carcinogenesis. Journal of Clinical Oncology 28 4425-4433. (https:// doi.org/10.1200/JCO.2010.28.0198)

Choi J, Chen J, Schreiber SL \& Clardy J 1996 Structure of the FKBP12rapamycin complex interacting with binding domain of human FRAP. Science 273 239-242. (https://doi.org/10.1126/ science.273.5272.239)

Choo AY, Yoon S-O, Kim SG, Roux PP \& Blenis J 2008 Rapamycin differentially inhibits S6Ks and 4E-BP1 to mediate cell-type-specific repression of mRNA translation. PNAS 105 17414-17419. (https:// doi.org/10.1073/pnas.0809136105)

Conteduca V, Aieta M, Amadori D \& De Giorgi U 2014 Neuroendocrine differentiation in prostate cancer: current and emerging therapy strategies. Critical Reviews in Oncology/Hematology 92 11-24. (https:// doi.org/10.1016/j.critrevonc.2014.05.008)

Cooke VG, LeBleu VS, Keskin D, Khan Z, O'Connell JT, Teng Y, Duncan MB, Xie L, Maeda G, Vong S, et al. 2012 Pericyte depletion results in hypoxia-associated epithelial-to-mesenchymal transition and metastasis mediated by met signaling pathway. Cancer Cell $\mathbf{2 1}$ 66-81. (https://doi.org/10.1016/j.ccr.2011.11.024)

Cottu P, Bièche I, Assayag F, El Botty R, Chateau-Joubert S, Thuleau A, Bagarre T, Albaud B, Rapinat A, Gentien D, et al. 2014 Acquired resistance to endocrine treatments is associated with tumor-specific molecular changes in patient-derived luminal breast cancer xenografts. Clinical Cancer Research 20 4314-4325. (https://doi. org/10.1158/1078-0432.CCR-13-3230)

Couvelard A \& Sauvanet A 2008 Gastroenteropancreatic neuroendocrine tumors: indications for and pitfalls of frozen section examination. Virchows Archiv 453 441-448. (https://doi. org/10.1007/s00428-008-0678-6)

Couvelard A, O'Toole D, Turley H, Leek R, Sauvanet A, Degott C, Ruszniewski P, Belghiti J, Harris AL, Gatter K, et al. 2005 Microvascular density and hypoxia-inducible factor pathway in https://erc.bioscientifica.com

https://doi.org/10.1530/ERC-18-0420 (c) 2019 Society for Endocrinology Published by Bioscientifica Ltd. Printed in Great Britain 
pancreatic endocrine tumours: negative correlation of microvascular density and VEGF expression with tumour progression. British Journal of Cancer 92 94-101. (https://doi.org/10.1038/sj.bjc.6602245)

Crona J \& Skogseid B 2016 GEP- NETS UPDATE: genetics of neuroendocrine tumors. European Journal of Endocrinology $\mathbf{1 7 4}$ R275-R290. (https://doi.org/10.1530/EJE-15-0972)

Cros J, Moati E, Raffenne J, Hentic O, Svrcek M, De Mestier L, Sbidian E, Guedj N, Bedossa P, Paradis V, et al. 2016 Gly388Arg FGFR4 polymorphism is not predictive of everolimus efficacy in welldifferentiated digestive neuroendocrine tumors. Neuroendocrinology 103 495-499. (https://doi.org/10.1159/000440724)

Cross DA, Alessi DR, Cohen P, Andjelkovich M \& Hemmings BA 1995 Inhibition of glycogen synthase kinase-3 by insulin mediated by protein kinase B. Nature $\mathbf{3 7 8} 785-789$. (https://doi. org/10.1038/378785a0)

Daniel VC, Marchionni L, Hierman JS, Rhodes JT, Devereux WL, Rudin CM, Yung R, Parmigiani G, Dorsch M, Peacock CD, et al. 2009 A primary xenograft model of small-cell lung cancer reveals irreversible changes in gene expression imposed by culture in vitro. Cancer Research 69 3364-3373. (https://doi.org/10.1158/0008-5472.CAN-08-4210)

Dasari A, Shen C, Halperin D, Zhao B, Zhou S, Xu Y, Shih T \& Yao JC 2017 Trends in the incidence, prevalence, and survival outcomes in patients with neuroendocrine tumors in the United States. JAMA Oncology 3 1335-1342. (https://doi.org/10.1001/ jamaoncol.2017.0589)

Datta SR, Dudek H, Xu T, Masters S, Haian F, Gotoh Y \& Greenberg ME 1997 Akt phosphorylation of BAD couples survival signals to the cell- intrinsic death machinery. Cell 91 231-241. (https://doi. org/10.1016/S0092-8674(00)80405-5)

Dibble CC, Elis W, Menon S, Qin W, Klekota J, Asara JM, Finan PM, Kwiatkowski DJ, Murphy LO \& Manning BD 2012 TBC1D7 is a third subunit of the TSC1-TSC2 complex upstream of mTORC1. Molecular Cell 47 535-546. (https://doi.org/10.1016/j.molcel.2012.06.009)

Dilling MB, Germain GS, Dudkin L, Jayaraman AL, Zhang X, Harwood FC \& Houghton PJ 2002 4E-binding proteins, the suppressors of eukaryotic initiation factor $4 \mathrm{E}$, are down-regulated in cells with acquired or intrinsic resistance to rapamycin. Journal of Biological Chemistry 277 13907-13917. (https://doi.org/10.1074/jbc. M110782200)

Dimaras H \& Gallie BL 2008 The p75NTRneurotrophin receptor is a tumor suppressor in human and murine retinoblastoma development. International Journal of Cancer 122 2023-2029. (https:// doi.org/10.1002/ijc.23356)

Dumont FJ, Staruch MJ, Grammer T, Blenis J, Kastner CA \& Rupprecht KM 1995 Dominant mutations confer resistance to the immunosuppressant, rapamycin, in variants of a T cell lymphoma. Cellular Immunology 163 70-79. (https://doi.org/10.1006/cimm.1995.1100)

Earwaker P, Anderson C, Willenbrock F, Harris AL, Protheroe AS \& Macaulay VM 2018 RAPTOR up-regulation contributes to resistance of renal cancer cells to PI3K-mTOR inhibition. PLOS ONE $\mathbf{1 3}$ e0191890. (https://doi.org/10.1371/journal.pone.0191890)

Engelman JA, Luo J \& Cantley LC 2006 The evolution of phosphatidylinositol 3-kinases as regulators of growth and metabolism. Nature Reviews Genetics 7 606-619. (https://doi. org/10.1038/nrg1879)

Eriksson B \& Öberg K 2000 Neuroendocrine tumours of the pancreas. British Journal of Surgery 87 129-131. (https://doi. org/10.1046/j.1365-2168.2000.01277.x)

Faivre S, Kroemer G \& Raymond E 2006 Current development of mTOR inhibitors as anticancer agents. Nature Reviews Drug Discovery 5 671-688. (https://doi.org/10.1038/nrd2062)

Fan QW, Aksoy O, Wong RA, Ilkhanizadeh S, Novotny CJ, Gustafson WC, Truong AYQ, Cayanan G, Simonds EF, Haas-Kogan D, et al. 2017 A kinase inhibitor targeted to mTORC1 drives regression in glioblastoma. Cancer Cell 31 424-435. (https://doi.org/10.1016/j. ccell.2017.01.014)
Fazio N, Buzzoni R, Baudin E, Antonuzzo L, Hubner RA, Lahner H, De Herder WW, Raderer M, Teulé A, Capdevila J, et al. 2016 A phase II study of BEZ235 in patients with everolimus-resistant, advanced pancreatic neuroendocrine tumours. Anticancer Research 36 713-720. (https://doi.org/10.1161/CIRCRESAHA.116.303790)

Feldman ME, Apsel B, Uotila A, Loewith R, Knight ZA, Ruggero D \& Shokat KM 2009 Active-site inhibitors of mTOR target rapamycinresistant outputs of mTORC1 and mTORC2. PLoS Biology 7 0371-0383. (https://doi.org/10.1371/journal.pbio.1000038)

Filippakopoulos P \& Knapp S 2014 Targeting bromodomains: epigenetic readers of lysine acetylation. Nature Reviews Drug Discovery 13 337-356. (https://doi.org/10.1038/nrd4286)

Folkman J \& Shing Y 1992 Angiogenesis. Journal of Biological Chemistry 267 10931-10934.

Folkman J, Watson K, Ingber D \& Hanahan D 1989 Induction of angiogenesis during the transition from hyperplasia to neoplasia. Nature 339 58-61. (https://doi.org/10.1038/339058a0)

Fruman DA \& Rommel C 2014 PI3K and cancer: lessons, challenges and opportunities. Nature Reviews Drug Discovery 13 140-156. (https:// doi.org/10.1038/nrd4204)

Ghayouri M, Boulware D, Nasir A, Strosberg J, Kvols L \& Coppola D 2010 Activation of the serine/theronine protein kinase akt in enteropancreatic neuroendocrine tumors. Anticancer Research 30 5063-5068.

Gingras AC, Raught B, Gygi SP, Niedzwiecka A, Miron M, Burley SK, Polakiewicz RD, Wyslouch-Cieszynska A, Aebersold R \& Sonenberg N 2001 Hierarchical phosphorylation of the translation inhibitor 4E-BP1. Genes and Development 15 2852-2864. (https://doi. org/10.1101/gad.912401)

Goodman VL, Rock EP, Dagher R, Ramchandani RP, Abraham S, Gobburu JVS, Booth BP, Verbois SL, Morse DE, Liang CY, et al. 2007 Approval summary: sunitinib for the treatment of imatinib refractory or intolerant gastrointestinal stromal tumors and advanced renal cell carcinoma. Clinical Cancer Research $\mathbf{1 3}$ 1367-1373. (https://doi.org/10.1158/1078-0432.CCR-06-2328)

Gotink KJ, Broxterman HJ, Labots M, De Haas RR, Dekker H, Honeywell RJ, Rudek MA, Beerepoot L V., Musters RJ, Jansen G, et al. 2011 Lysosomal sequestration of sunitinib: a novel mechanism of drug resistance. Clinical Cancer Research 17 7337-7346. (https://doi. org/10.1158/1078-0432.CCR-11-1667)

Gotink KJ, Rovithi M, de Haas RR, Honeywell RJ, Dekker H, Poel D, Azijli K, Peters GJ, Broxterman HJ \& Verheul HMW 2015 Cross-resistance to clinically used tyrosine kinase inhibitors sunitinib, sorafenib and pazopanib. Cellular Oncology 38 119-129. (https://doi.org/10.1007/s13402-015-0218-8)

Grabowski P, Griß S, Arnold CN, Hörsch D, Göke R, Arnold R, Heine B, Stein H, Zeitz M \& Scherübl H 2005 Nuclear survivin is a powerful novel prognostic marker in gastroenteropancreatic neuroendocrine tumor disease. Neuroendocrinology 81 1-9. (https://doi.org/10.1159/000084892)

Guri Y, Colombi M, Dazert E, Hindupur SK, Roszik J, Moes S, Jenoe P, Heim MH, Riezman I, Riezman H, et al. 2017 mTORC2 promotes tumorigenesis via lipid synthesis. Cancer Cell 32 807.e12-823.e12. (https://doi.org/10.1016/j.ccell.2017.11.011)

Hammerman PS, Fox CJ, Birnbaum MJ \& Thompson CB 2005 Pim and Akt oncogenes are independent regulators of hematopoietic cell growth and survival. Blood 105 4477-4483. (https://doi.org/10.1182/ blood-2004-09-3706)

Hanahan D 1985 Heritable formation of pancreatic $\beta$-cell tumours in transgenic mice expressing recombinant insulin/simian virus 40 oncogenes. Nature 315 115-122. (https://doi.org/10.1038/315115a0)

Hanahan D \& Weinberg RA 2011 Hallmarks of cancer: the next generation. Cell 144 646-674. (https://doi.org/10.1016/j. cell.2011.02.013)

Harrington LS, Findlay GM, Gray A, Tolkacheva T, Wigfield S, Rebholz H, Barnett J, Leslie NR, Cheng S, Shepherd PR, et al. 2004 The TSC1-2 tumor suppressor controls insulin-PI3K signaling via 
regulation of IRS proteins. Journal of Cell Biology 166 213-223. (https://doi.org/10.1083/jcb.200403069)

Hay N 2005 The Akt-mTOR tango and its relevance to cancer. Cancer Cell 8 179-183. (https://doi.org/10.1016/j.ccr.2005.08.008)

Heitman J, Movva NR, Hiestand PC \& Hall MN 1991 FK 506-binding protein proline rotamase is a target for the immunosuppressive agent FK 506 in Saccharomyces cerevisiae. PNAS 88 1948-1952. (https://doi.org/10.1073/pnas.88.5.1948)

Heldin CH \& Westermark B 1999 Mechanism of action and in vivo role of platelet-derived growth factor. Physiological Reviews 79 1283-1316. (https://doi.org/10.1146/annurev.ph.57.030195.001501)

Hervouet E, Cheray M, Vallette F \& Cartron P-F 2013 DNA methylation and apoptosis resistance in cancer cells. Cells 2 545-573. (https://doi. org/10.3390/cells2030545)

Hesselson D, Anderson RM, Beinat M \& Stainier DYR 2009 Distinct populations of quiescent and proliferative pancreatic -cells identified by HOTcre mediated labeling. PNAS 106 14896-14901. (https://doi. $\operatorname{org} / 10.1073 /$ pnas.0906348106)

Hofland J, Zandee WT \& de Herder WW 2018 Role of biomarker tests for diagnosis of neuroendocrine tumours. Nature Reviews Endocrinology 14 656-669. (https://doi.org/10.1038/s41574-0180082-5)

Hosoi H, Dilling MB, Shikata T, Liu LN, Shu L, Ashmun RA, Germain GS, Abraham RT \& Houghton PJ 1999 Rapamycin causes poorly reversible inhibition of mTOR and induces p53-independent apoptosis in human rhabdomyosarcoma cells. Cancer Research 59 886-894. (https://doi.org/10.1038/369756a0)

Hsu PP, Kang SA, Rameseder J, Zhang Y, Ottina KA, Lim D, Peterson TR, Choi Y, Gray NS, Yaffe MB, et al. 2011 The mTOR-regulated phosphoproteome reveals a mechanism of mTORC1-mediated inhibition of growth factor signaling. Science 332 1317-1322. (https://doi.org/10.1126/science.1199498)

Inoki K, Li Y, Zhu T, Wu J \& Guan KL 2002 TSC2 is phosphorylated and inhibited by Akt and suppresses mTOR signalling. Nature Cell Biology 4 648-657. (https://doi.org/10.1038/ncb839)

Iyer N V, Kotch LE, Agani F, Leung SW, Laughner E, Wenger RH, Gassmann M, Gearhart JD, Lawler a M, Yu a Y, et al. 1998 Cellular and developmental control of $\mathrm{O} 2$ homeostasis by hypoxia-inducible factor 1 alpha. Genes and Development 12 149-162. (https://doi. org/10.1101/gad.12.2.149)

Jacinto E, Loewith R, Schmidt A, Lin S, Rüegg MA, Hall A \& Hall MN 2004 Mammalian TOR complex 2 controls the actin cytoskeleton and is rapamycin insensitive. Nature Cell Biology 6 1122-1128. (https://doi.org/10.1038/ncb1183)

Jain RK 2003 Molecular regulation of vessel maturation. Nature Medicine 9 685-693. (https://doi.org/10.1038/nm0603-685)

Jakeman LB, Winer J, Bennett GL, Altar CA \& Ferrara N 1992 Binding sites for vascular endothelial growth factor are localized on endothelial cells in adult rat tissues. Journal of Clinical Investigation 89 244-253. (https://doi.org/10.1172/JCI115568)

Jiao Y, Shi C, Edil BH, de Wilde RF, Klimstra DS, Maitra A, Schulick RD, Tang LH, Wolfgang CL, Choti MA, et al. 2011 DAXX/ATRX, MEN1, and mTOR pathway genes are frequently altered in pancreatic neuroendocrine tumors. Science 331 1199-1203. (https://doi. org/10.1126/science.1200609)

Jin H, Pan Y, He L, Zhai H, Li X, Zhao L, Sun L, Liu J, Hong L, Song J, et al. 2007 p75 neurotrophin receptor inhibits invasion and metastasis of gastric cancer. Molecular Cancer Research 5 423-433. (https://doi.org/10.1158/1541-7786.MCR-06-0407)

Joyce JA, Laakkonen P, Bernasconi M, Bergers G, Ruoslahti E \& Hanahan D 2003 Stage-specific vascular markers revealed by phage display in a mouse model of pancreatic islet tumorigenesis. Cancer Cell 4 393-403. (https://doi.org/10.1016/S1535-6108(03)00271-X)

Juengel E, Dauselt A, Makarević J, Wiesner C, Tsaur I, Bartsch G, Haferkamp A \& Blaheta RA 2012 Acetylation of histone H3 prevents resistance development caused by chronic mTOR inhibition in renal cell carcinoma cells. Cancer Letters 324 83-90. (https://doi. org/10.1016/j.canlet.2012.05.003)

Juengel E, Nowaz S, Makarevi J, Natsheh I, Werner I, Nelson K, Reiter M, Tsaur I, Mani J, Harder S, et al. 2014 HDAC-inhibition counteracts everolimus resistance in renal cell carcinoma in vitro by diminishing cdk2 and cyclin A. Molecular Cancer 13 152. (https://doi. org/10.1186/1476-4598-13-152)

Juengel E, Najafi R, Rutz J, Maxeiner S, Makarevic J, Roos F, Tsaur I, Haferkamp A \& Blaheta RA 2017 HDAC inhibition as a treatment concept to combat temsirolimus-resistant bladder cancer cells. Oncotarget 8 110016-110028. (https://doi.org/10.18632/ oncotarget.22454)

Kanakis G \& Kaltsas G 2012 Biochemical markers for gastroenteropancreatic neuroendocrine tumours (GEP-NETs). Best Practice and Research: Clinical Gastroenterology 26 791-802. (https:// doi.org/10.1016/j.bpg.2012.12.006)

Karar J \& Maity A 2011 PI3K/AKT/mTOR pathway in angiogenesis. Frontiers in Molecular Neuroscience 4 51. (https://doi.org/10.3389/ fnmol.2011.00051)

Kasajima A, Pavel M, Darb-Esfahani S, Noske A, Stenzinger A, Sasano H, Dietel M, Denkert C, Röcken C, Wiedenmann B, et al. 2011 mTOR expression and activity patterns in gastroenteropancreatic neuroendocrine tumours. Endocrine-Related Cancer 18 181-192. (https://doi.org/10.1677/ERC-10-0126)

Katsha A, Wang L, Arras J, Omar OM, Ecsedy J, Belkhiri A \& El-Rifai W 2017 Activation of EIF4E by Aurora kinase A depicts a novel druggable axis in everolimus-resistant cancer cells. Clinical Cancer Research 23 3756-3768. (https://doi.org/10.1158/1078-0432.CCR-162141)

Kawase T, Ohki R, Shibata T, Tsutsumi S, Kamimura N, Inazawa J, Ohta T, Ichikawa H, Aburatani H, Tashiro F, et al. 2009 PH domainonly protein PHLDA3 is a p53-regulated repressor of Akt. Cell 136 535-550. (https://doi.org/10.1016/j.cell.2008.12.002)

Keck PJ, Hauser SD, Krivi G, Sanzo K, Warren T, Feder J \& Connolly DT 1989 Vascular permeability factor, an endothelial cell mitogen related to PDGF. Science 246 1309-1312. (https://doi.org/10.1126/ science.2479987)

Kelly TK, De Carvalho DD \& Jones PA 2010 Epigenetic modifications as therapeutic targets. Nature Biotechnology 28 1069-1078. (https://doi. org/10.1038/nbt.1678)

Knight ZA, Gonzalez B, Feldman ME, Zunder ER, Goldenberg DD, Williams O, Loewith R, Stokoe D, Balla A, Toth B, et al. 2006 A pharmacological map of the PI3-K family defines a role for $\mathrm{p} 110 \alpha$ in insulin signaling. Cell 125 733-747. (https://doi.org/10.1016/j. cell.2006.03.035)

Kobayashi A, Takahashi M, Imai H, Akiyama S, Sugiyama S, Komine K, Saijo K, Takahashi M, Takahashi S, Shirota H, et al. 2016 Attainment of a long-term favorable outcome by sunitinib treatment for pancreatic neuroendocrine tumor and renal cell carcinoma associated with von Hippel-Lindau disease. Internal Medicine $\mathbf{5 5}$ 629-634. (https://doi.org/10.2169/internalmedicine.55.5796)

Koltin Y, Faucette L, Bergsma DJ, Levy MA, Cafferkey R, Koser PL, Johnson RK \& Livi GP 1991 Rapamycin sensitivity in Saccharomyces cerevisiae is mediated by a peptidyl-prolyl cis-trans isomerase related to human \{FK506-binding\} protein. Molecular and Cellular Biology. 11 1718-1723. (https://doi.org/10.1128/MCB.11.3.1718.Updated)

Küchler J, Hartmann W, Waha A, Koch A, Endl E, Wurst P, Kindler D, Mikeska T, Waha A, Goodyer CG, et al. 2011 P75NTRinduces apoptosis in medulloblastoma cells. International Journal of Cancer 128 1804-1812. (https://doi.org/10.1002/ijc.25508)

Kulke MH, Lenz HJ, Meropol NJ, Posey J, Ryan DP, Picus J, Bergsland E, Stuart K, Tye L, Huang X, et al. 2008 Activity of sunitinib in patients with advanced neuroendocrine tumors. Journal of Clinical Oncology 26 3403-3410. (https://doi.org/10.1200/JCO.2007.15.9020)

Kulke M, Niedzwiecki D, Foster N, Fruth B, Kunz P, Kennecke H, Wolin E \& Venook A 2016 Randomized phase II study of everolimus https://erc bioscientifica com

https://doi.org/10.1530/ERC-18-0420
(C) 2019 Society for Endocrinology Published by Bioscientifica Ltd. Printed in Great Britain 
(E) versus everolimus plus bevacizumab (E+B) in patients (Pts) with locally advanced or metastatic pancreatic neuroendocrine tumors (pNET), CALGB 80701 (Alliance). Abstracts presented at the 8th Annual Meeting of the North American NeuroEndocrine Tumor Society, October 14-18, 2015, Austin, Texas. Pancreas 45477. (https://doi.org/10.1097/MPA.000000000000615)

Lamberti G, Ceccarelli C, Brighi N, Maggio I, Santini D, Mosconi C, Ricci C, Biasco G \& Campana D 2017 Determination of mammalian target of rapamycin hyperactivation as prognostic factor in welldifferentiated neuroendocrine tumors. Gastroenterology Research and Practice 2017 9. (https://doi.org/10.1155/2017/7872519)

Lane HA, Wood JM, McSheehy PMJ, Allegrini PR, Boulay A, Brueggen J, Littlewood-Evans A, Maira SM, Martiny-Baron G, Schnell CR, et al. 2009 mTOR inhibitor RAD001 (Everolimus) has anti-angiogenic/ vascular properties distinct from a VEGFR tyrosine kinase inhibitor. Clinical Cancer Research 15 1612-1622. (https://doi. org/10.1158/1078-0432.CCR-08-2057)

Liao D \& Johnson RS 2007 Hypoxia: a key regulator of angiogenesis in cancer. Cancer and Metastasis Reviews 26 281-290. (https://doi. org/10.1007/s10555-007-9066-y)

Lilly M \& Kraft A 1997 Enforced expression of the M(r) 33,000 Pim-1 kinase enhances factor- independent survival and inhibits apoptosis in murine myeloid cells. Cancer Research 57 5348-5355.

Lindahl M, Poteryaev D, Yu L, Arumäe U, Timmusk T, Bongarzone I, Aiello A, Pierotti MA, Airaksinen MS \& Saarma M 2001 Human glial cell line-derived neurotrophic factor receptor $\alpha 4$ is the receptor for persephin and is predominantly expressed in normal and malignant thyroid medullary cells. Journal of Biological Chemistry 276 9344-9351. (https://doi.org/10.1074/jbc.M008279200)

Liu P, Cheng H, Roberts TM \& Zhao JJ 2009 Targeting the phosphoinositide 3-kinase (PI3K) pathway in cancer. Nature Reviews Drug Discovery. 8 627-644. (https://doi.org/10.1038/nrd2926. Targeting)

Logan R, Kong A \& Krise JP 2013 Evaluating the roles of autophagy and lysosomal trafficking defects in intracellular distribution-based drugdrug interactions involving lysosomes. Journal of Pharmaceutical Sciences 102 4173-4180. (https://doi.org/10.1002/jps.23706)

Luo Y, Marx SO, Kiyokawa H, Koff a, Massagué J \& Marks a R 1996 Rapamycin resistance tied to defective regulation of p27Kip1. Molecular and Cellular Biology 16 6744-6751. (https://doi. org/10.1128/MCB.16.12.6744)

Lyons RM, Keski-Oja J \& Moses HL 1988 Proteolytic activation of latent transforming growth factor-beta from fibroblast-conditioned medium. Journal of Cell Biology 106 1659-1665. (https://doi. org/10.1083/jcb.106.5.1659)

Ma XM \& Blenis J 2009 Molecular mechanisms of mTOR-mediated translational control. Nature Reviews Molecular Cell Biology 10 307-318. (https://doi.org/10.1038/nrm2672)

Ma L, Chen Z, Erdjument-Bromage H, Tempst P \& Pandolfi PP 2005 Phosphorylation and functional inactivation of TSC2 by Erk: implications for tuberous sclerosis and cancer pathogenesis. Cell 121 179-193. (https://doi.org/10.1016/j.cell.2005.02.031)

Maione F, Capano S, Regano D, Zentilin L, Giacca M, Casanovas O, Bussolino F, Serini G \& Giraudo E 2012 Semaphorin 3A overcomes cancer hypoxia and metastatic dissemination induced by antiangiogenic treatment in mice. Journal of Clinical Investigation 122 1832-1848. (https://doi.org/10.1172/JCI58976)

Maira S-M, Stauffer F, Brueggen J, Furet P, Schnell C, Fritsch C, Brachmann S, Chene P, De Pover A, Schoemaker K, et al. 2008 Identification and characterization of NVP-BEZ235, a new orally available dual phosphatidylinositol 3-kinase/mammalian target of rapamycin inhibitor with potent in vivo antitumor activity. Molecular Cancer Therapeutics 7 1851-1863. (https://doi. org/10.1158/1535-7163.MCT-08-0017)

Majumder PK, Febbo PG, Bikoff R, Berger R, Xue Q, McMahon LM, Manolal J, Brugarolas J, McDonnell TJ Golub TR, et al. 2004 mTOR inhibition reverses Akt-dependent prostate intraepithelial neoplasia through regulation of apoptotic and HIF-1-dependent pathways. Nature Medicine 10 594-601. (https://doi.org/10.1038/nm1052)

Makarević J, Rutz J, Juengel E, Maxeiner S, Mani J, Vallo S, Tsaur I, Roos F, Chun F \& Blaheta R 2018 HDAC inhibition counteracts metastatic re-activation of prostate cancer cells induced by chronic mTOR suppression. Cells 7 129. (https://doi.org/10.3390/ cells7090129)

Mateo J, Olmos D, Dumez H, Poondru S, Samberg NL, Barr S, Van Tornout JM, Jie F, Sandhu S, Tan DS, et al. 2016 A first in man, dosefinding study of the mTORC1/mTORC2 inhibitor OSI-027 in patients with advanced solid malignancies. British Journal of Cancer 114 889-896. (https://doi.org/10.1038/bjc.2016.59)

Matsumoto M, Seike M, Noro R, Soeno C, Sugano T, Takeuchi S, Miyanaga A, Kitamura K, Kubota K \& Gemma A 2015 Control of the MYC-eIF4E axis plus mTOR inhibitor treatment in small cell lung cancer. BMC Cancer 15 241. (https://doi.org/10.1186/s12885-0151202-4)

Maxwell PH, Wlesener MS, Chang GW, Clifford SC, Vaux EC, Cockman ME, Wykoff CC, Pugh CW, Maher ER \& Ratcliffe PJ 1999 The tumour suppressor protein VHL targets hypoxia-inducible factors for oxygen-dependent proteolysis. Nature 399 271-275. (https://doi.org/10.1038/20459)

Mendel DB, Laird AD, Xin X, Louie SG, Christensen JG, Li G, Schreck RE, Abrams TJ, Ngai TJ, Lee LB, et al. 2003 In vivo antitumor activity of SU11248, a novel tyrosine kinase inhibitor targeting vascular endothelial growth factor and platelet-derived growth factor receptors. Clinical Cancer Research 9 327-337.

Missiaglia E, Dalai I, Barbi S, Beghelli S, Falconi M, Della Peruta M, Piemonti L, Capurso G, Di Florio A, Delle Fave G, et al. 2010 Pancreatic endocrine tumors: expression profiling evidences a role for AKT-mTOR pathway. Journal of Clinical Oncology 28 245-255. (https://doi.org/10.1200/JCO.2008.21.5988)

Mitry E, Walter T, Baudin E, Kurtz JE, Ruszniewski P, DominguezTinajero S, Bengrine-Lefevre L, Cadiot G, Dromain C, Farace F, et al. 2014 Bevacizumab plus capecitabine in patients with progressive advanced well-differentiated neuroendocrine tumors of the gastrointestinal (GI-NETs) tract (BETTER trial) - a phase II non-randomised trial. European Journal of Cancer 50 3107-3115. (https://doi.org/10.1016/j.ejca.2014.10.001)

Mori S, Nada S, Kimura H, Tajima S, Takahashi Y, Kitamura A, Oneyama C \& Okada M 2014 The mTOR pathway controls cell proliferation by regulating the FoxO3a transcription factor via SGK1 kinase. PLOS ONE 9 e88891. (https://doi.org/10.1371/journal. pone.0088891)

Nathan CA, Carter P, Liu L, Li BD, Abreo F, Tudor A, Zimmer SG \& De Benedetti A 1997 Elevated expression of eIF4E and FGF-2 isoforms during vascularization of breast carcinomas. Oncogene 15 1087-1094. (https://doi.org/10.1038/sj.onc.1201272)

Neklesa TK \& Davis RW 2008 Superoxide anions regulate TORC1 and its ability to bind Fpr1: rapamycin complex. PNAS 105 15166-15171. (https://doi.org/10.1073/pnas.0807712105)

Nölting S, Rentsch J, Freitag H, Detjen K, Briest F, Möbs M, Weissmann V, Siegmund B, Auernhammer CJ, Aristizabal Prada ET, et al. 2017 The selective PI3Ko inhibitor BYL719 as a novel therapeutic option for neuroendocrine tumors: results from multiple cell line models. PLOS ONE 12 e0182852. (https://doi.org/10.1371/ journal.pone.0182852)

Nyfeler B, Chen Y, Li X, Pinzon-Ortiz M, Wang Z, Reddy A, Pradhan E, Das R, Lehár J, Schlegel R, et al. 2012 RAD001 enhances the potency of BEZ235 to inhibit mTOR signaling and tumor growth. PLOS ONE 7 e48548. (https://doi.org/10.1371/journal.pone.0048548)

O'Donnell A, Faivre S, Burris HA 3rd, Rea D, Papadimitrakopoulou V, Shand N, Lane HA, Hazell K, Zoellner U, Kovarik JM, et al. 2008 Phase I pharmacokinetic and pharmacodynamic study of the oral mammalian target of rapamycin inhibitor everolimus in patients (c) 2019 Society for Endocrinology Published by Bioscientifica Ltd. Printed in Great Britain 
with advanced solid tumors. Journal of Clinical Oncology $\mathbf{2 6}$ 1588-1595. (https://doi.org/10.1200/JCO.2007.14.0988)

Oberg K, Casanovas O, Castaño JP, Chung D, Delle Fave G, Denèfle P, Harris P, Khan MS, Kulke MH, Scarpa A, et al. 2013 Molecular pathogenesis of neuroendocrine tumors: implications for current and future therapeutic approaches. Clinical Cancer Research 19 2842-2849. (https://doi.org/10.1158/1078-0432.CCR-12-3458)

Oberg K, Couvelard A, Delle Fave G, Gross D, Grossman A, Jensen RT, Pape UF, Perren A, Rindi G, Ruszniewski P, et al. 2017 ENETS consensus guidelines for the standards of care in neuroendocrine tumors: biochemical markers. Neuroendocrinology 90 194-202. (https://doi.org/10.1159/000472254)

Ohki R, Saito K, Chen Y, Kawase T, Hiraoka N, Saigawa R, Minegishi M, Aita Y, Yanai G, Shimizu H, et al. 2014 PHLDA3 is a novel tumor suppressor of pancreatic neuroendocrine tumors. PNAS 111 E2404-E2413. (https://doi.org/10.1073/pnas.1319962111)

Oki Y, Buglio D, Fanale M, Fayad L, Copeland A, Romaguera J, Kwak LW, Pro B, De Castro Faria S, Neelapu S, et al. 2013 Phase I study of panobinostat plus everolimus in patients with relapsed or refractory lymphoma. Clinical Cancer Research 19 6882-6890. (https://doi.org/10.1158/1078-0432.CCR-13-1906)

Onrust SV, Hartl PM, Rosen SD \& Hanahan D 1996 Modulation of L-selectin ligand expression during an immune response accompanying tumorigenesis in transgenic mice. Journal of Clinical Investigation 97 54-64. (https://doi.org/10.1172/JCI118406)

Oshiro N, Yoshino KI, Hidayat S, Tokunaga C, Hara K, Eguchi S, Avruch J \& Yonezawa K 2004 Dissociation of raptor from mTOR is a mechanism of rapamycin-induced inhibition of mTOR function. Genes to Cells 9 359-366. (https://doi. org/10.1111/j.1356-9597.2004.00727.x)

Pàez-Ribes M, Allen E, Hudock J, Takeda T, Okuyama H, Viñals F, Inoue M, Bergers G, Hanahan D \& Casanovas O 2009 Antiangiogenic therapy elicits malignant progression of tumors to increased local invasion and distant metastasis. Cancer Cell 15 220-231. (https://doi.org/10.1016/j.ccr.2009.01.027)

Palm W, Park Y, Wright K, Pavlova NN, Tuveson DA \& Thompson CB 2015 The utilization of extracellular proteins as nutrients is suppressed by mTORC1. Cell 162 259-270. (https://doi. org/10.1016/j.cell.2015.06.017)

Passacantilli I, Capurso G, Archibugi L, Calabretta S, Caldarola S, Loreni F, Delle Fave G \& Sette C 2014 Combined therapy with RAD001 e BEZ235 overcomes resistance of PET immortalized cell lines to mTOR inhibition. Oncotarget 5 5381-5391. (https://doi. org/10.18632/oncotarget.2111)

Perren A, Komminoth P, Saremaslani P, Matter C, Feurer S, Lees JA, Heitz PU \& Eng C 2000 Mutation and expression analyses reveal differential subcellular compartmentalization of PTEN in endocrine pancreatic tumors compared to normal islet cells. American Journal of Pathology 157 1097-1103. (https://doi.org/10.1016/S00029440(10)64624-X)

Pinato DJ, Tan TM, Toussi STK, Ramachandran R, Martin N, Meeran K, Ngo N, Dina R \& Sharma R 2014 An expression signature of the angiogenic response in gastrointestinal neuroendocrine tumours: correlation with tumour phenotype and survival outcomes. British Journal of Cancer 110 115-122. (https://doi.org/10.1038/ bjc.2013.682)

Power RF, Holm R, Bishop AE, Varndell IM, Alpert S, Hanahan D \& Polak JM 1987 Transgenic mouse model: a new approach for the investigation of endocrine pancreatic B-cell growth. Gut $\mathbf{2 8}$ (Supplement) 121-129. (https://doi.org/10.1136/gut.28.Suppl.121)

Powles T, Wheater M, Din O, Geldart T, Boleti E, Stockdale A, Sundar S, Robinson A, Ahmed I, Wimalasingham A, et al. 2016 A randomised phase 2 study of AZD2014 versus everolimus in patients with VEGFrefractory metastatic clear cell renal cancer. European Urology 69 450-456. (https://doi.org/10.1016/j.eururo.2015.08.035)
Quinn TP, Peters KG, De Vries C, Ferrara N \& Williams LT 1993 Fetal liver kinase 1 is a receptor for vascular endothelial growth factor and is selectively expressed in vascular endothelium. PNAS 90 7533-7. (https://doi.org/10.1073/pnas.90.16.7533)

Raymond E, Dahan L, Raoul J-L, Bang Y-J, Borbath I, Lombard-Bohas C, Valle J, Metrakos P, Smith D, Vinik A, et al. 2011 Sunitinib malate for the treatment of pancreatic neuroendocrine tumors. New England Journal of Medicine 364 501-513. (https://doi.org/10.1056/ NEJMoa1003825)

Richard S, Gardie B, Couvé S \& Gad S 2013 Von Hippel-Lindau: how a rare disease illuminates cancer biology. Seminars in Cancer Biology 23 26-37. (https://doi.org/10.1016/j.semcancer.2012.05.005)

Rini BI, Garcia JA, Cooney MM, Elson P, Tyler A, Beatty K, Bokar J, Mekhail T, Bukowski RM, Budd GT, et al. 2009 A phase I study of sunitinib plus bevacizumab in advanced solid tumors. Clinical Cancer Research 15 6277-6283. (https://doi.org/10.1158/1078-0432.CCR-090717)

Rodrik-Outmezguine VS, Okaniwa M, Yao Z, Novotny CJ, McWhirter C, Banaji A, Won H, Wong W, Berger M, De Stanchina E, et al. 2016 Overcoming mTOR resistance mutations with a new-generation mTOR inhibitor. Nature 534 272-276. (https://doi.org/10.1038/ nature17963)

Rosich L, Colomer D \& Roué G 2013 Autophagy controls everolimus (RAD001) activity in mantle cell lymphoma. Autophagy 9 115-117. (https://doi.org/10.4161/auto.22483)

Rosner M \& Hengstschläger M 2008 Cytoplasmic and nuclear distribution of the protein complexes mTORC1 and mTORC2: rapamycin triggers dephosphorylation and delocalization of the mTORC2 components rictor and sin1. Human Molecular Genetics 17 2934-2948. (https://doi.org/10.1093/hmg/ddn192)

Roux PP, Ballif BA, Anjum R, Gygi SP \& Blenis J 2004 Tumor-promoting phorbol esters and activated Ras inactivate the tuberous sclerosis tumor suppressor complex via p90 ribosomal S6 kinase. PNAS 101 13489-13494. (https://doi.org/10.1073/pnas.0405659101)

Rovira M, Huang W, Yusuff S, Shim JS, Ferrante AA, Liu JO \& Parsons MJ 2011 Chemical screen identifies FDA-approved drugs and target pathways that induce precocious pancreatic endocrine differentiation. PNAS 108 19264-19269. (https://doi.org/10.1073/ pnas.1113081108)

Rubinsztein DC, Gestwicki JE, Murphy LO \& Klionsky DJ 2007 Potential therapeutic applications of autophagy. Nature Reviews Drug Discovery 6 304-312. (https://doi.org/10.1038/nrd2272)

Salazar R, Garcia-Carbonero R, Libutti SK, Hendifar AE, Custodio A, Guimbaud R, Lombard-Bohas C, Ricci S, Klümpen H, Capdevila J, et al. 2017 Phase II study of BEZ235 versus everolimus in patients with mammalian target of rapamycin inhibitor-naïve advanced pancreatic neuroendocrine tumors. Oncologist 23 766-e90. (https:// doi.org/10.1634/theoncologist.2017-0144)

Sarbassov DD, Ali SM, Kim D-H, Guertin DA, Latek RR, ErdjumentBromage H, Tempst P \& Sabatini DM 2004 Rictor, a novel binding partner of mTOR, defines a rapamycin-insensitive and raptorindependent pathway that regulates the cytoskeleton. Current Biology, 14 1296-1302. (https://doi.org/10.1016/j)

Sarbassov DD, Guertin DA, Ali SM \& Sabatini DM 2005 Phosphorylation and regulation of Akt/PKB by the rictor-mTOR complex. Science $\mathbf{3 0 7}$ 1098-1101. (https://doi.org/10.1126/science.1106148)

Sato Y 1991 Regulators of angiogenesis. Annual Review of Physiology $\mathbf{5 3}$ 217-239. (https://doi.org/10.1146/annurev.physiol.53.1.217)

Saxton RA \& Sabatini DM 2017 mTOR signaling in growth, metabolism, and disease. Cell 168 960-976. (https://doi.org/10.1016/j. cell.2017.02.004

Scarpa A, Chang DK, Nones K, Corbo V, Patch A-M, Bailey P, Lawlor RT, Johns AL, Miller DK, Mafficini A, et al. 2017 Whole-genome landscape of pancreatic neuroendocrine tumours. Nature $\mathbf{5 4 3}$ 65-71. (https://doi.org/10.1038/nature21063) https://erc bioscientifica com

https://doi.org/10.1530/ERC-18-0420
C) 2019 Society for Endocrinology Published by Bioscientifica Ltd. Printed in Great Britain 
Schreiber KH, Ortiz D, Academia EC, Anies AC, Liao CY \& Kennedy BK 2015 Rapamycin-mediated mTORC2 inhibition is determined by the relative expression of FK506-binding proteins. Aging Cell $\mathbf{1 4}$ 265-273. (https://doi.org/10.1111/acel.12313)

Sehgal SN, Baker H \& Vézina C 1975 Rapamycin (AY-22,989), a new antifungal antibiotic. II. Fermentation, isolation and characterization. Journal of Antibiotics 28 727-732. (https://doi. org/10.7164/antibiotics.28.727)

Shah OJ, Wang Z \& Hunter T 2004 Inappropriate activation of the TSC/ Rheb/mTOR/S6K cassette induces IRS1/2 depletion, insulin resistance, and cell survival deficiencies. Current Biology 14 1650-1656. (https://doi.org/10.1016/j.cub.2004.08.026)

Shida T, Kishimoto T, Furuya M, Nikaido T, Koda K, Takano S, Kimura F, Shimizu H, Yoshidome H, Ohtsuka M, et al. 2010 Expression of an activated mammalian target of rapamycin (mTOR) in gastroenteropancreatic neuroendocrine tumors. Cancer Chemotherapy and Pharmacology 65 889-893. (https://doi.org/10.1007/s00280-0091094-6)

Shin I, Yakes FM, Rojo F, Shin N young, Bakin A V., Baselga J \& Arteaga CL 2002 PKB/Akt mediates cell-cycle progression by phosphorylation of p27Kip1at threonine 157 and modulation of its cellular localization. Nature Medicine 8 1145-1152. (https://doi. org/10.1038/nm759)

Sims DE 1986 The pericyte-A review. Tissue and Cell 18 153-174. (https://doi.org/10.1016/0040-8166(86)90026-1)

Singh K, Sun S \& Vezina C 1979 Rapamycin (AY-22,989), a new antifungal antibiotic. IV. Mechanism of action. Journal of Antibiotics 32 630-645. (https://doi.org/10.7164/antibiotics.32.630)

Soliman GA, Acosta-Jaquez HA, Dunlop EA, Ekim B, Maj NE, Tee AR \& Fingar DC 2010 mTOR Ser-2481 autophosphorylation monitors mTORC-specific catalytic activity and clarifies rapamycin mechanism of action. Journal of Biological Chemistry 285 7866-7879. (https://doi. org/10.1074/jbc.M109.096222)

Stokoe D, Stephens LR, Copeland T, Gaffney PR, Reese CB, Painter GF, Holmes a B, McCormick F \& Hawkins PT 1997 Dual role of phosphatidylinositol-3,4,5-trisphosphate in the activation of protein kinase B. Science 277 567-570. (https://doi.org/10.1126/ science.277.5325.567)

Strickler JH, Starodub AN, Jia J, Meadows KL, Nixon AB, Dellinger A, Morse MA, Uronis HE, Marcom PK, Zafar SY, et al. 2012 Phase I study of bevacizumab, everolimus, and panobinostat (LBH-589) in advanced solid tumors. Cancer Chemotherapy and Pharmacology 70 251-258. (https://doi.org/10.1007/s00280-012-1911-1)

Tan J, Lee PL, Li Z, Jiang X, Lim YC, Hooi SC \& Yu Q 2010 B55 $\beta$ associated PP2A complex controls PDK1-directed Myc signaling and modulates rapamycin sensitivity in colorectal cancer. Cancer Cell $\mathbf{1 8}$ 459-471. (https://doi.org/10.1016/j.ccr.2010.10.021)

Taylor M, Coleman RL \& Sood AK 2015 The role of angiogenesis in cancer. In Targeted Therapy in Translational Cancer Research, pp 64-71. Eds A-M Tsimberidou, R Kurzock \& KC Anderson. Hoboken, NJ, USA: John Wiley \& Sons Inc. (https://doi. org/10.1002/9781118468678.ch6)

Tehrani Z \& Lin S 2011 Endocrine pancreas development in zebrafish. Cell Cycle 10 3466-3472. (https://doi.org/10.4161/cc.10.20.17764)

Thoreen CC, Kang SA, Chang JW, Liu Q, Zhang J, Gao Y, Reichling LJ, Sim T, Sabatini DM \& Gray NS 2009 An ATP-competitive mammalian target of rapamycin inhibitor reveals rapamycinresistant functions of mTORC1. Journal of Biological Chemistry 284 8023-8032. (https://doi.org/10.1074/jbc.M900301200)

Thorpe LM, Yuzugullu H \& Zhao JJ 2015 PI3K in cancer: divergent roles of isoforms, modes of activation and therapeutic targeting. Nature Reviews Cancer 15 7-24. (https://doi.org/10.1038/nrc3860)

Tobia C, Gariano G, De Sena G \& Presta M 2013 Zebrafish embryo as a tool to study tumor/endothelial cell cross-talk. Biochimica et Biophysica Acta 1832 1371-1377. (https://doi.org/10.1016/j. bbadis.2013.01.016)
Townsend Jr CM, Ishizuka J \& Thompson JC 1993 Studies of growth regulation in a neuroendocrine cell line. Acta Oncologica 32 125-130. (https://doi.org/10.3109/02841869309083900)

Valentino JD, Li J, Zaytseva YY, Mustain WC, Elliott VA, Kim JT, Harris JW, Campbell K, Weiss H, Wang C, et al. 2014 Cotargeting the PI3K and RAS pathways for the treatment of neuroendocrine tumors. Clinical Cancer Research 20 1212-1222. (https://doi. org/10.1158/1078-0432.CCR-13-1897)

Vandamme T, Beyens M, De Beeck KO, Dogan F, Van Koetsveld PM, Pauwels P, Mortier G, Vangestel C, de Herder W Van Camp G, et al. 2016 Long-term acquired everolimus resistance in pancreatic neuroendocrine tumours can be overcome with novel PI3K-AKTmTOR inhibitors. British Journal of Cancer 114 650-658. (https://doi. org/10.1038/bjc.2016.25)

Vandamme T, Beyens M, Boons G, Schepers A, Kamp K, Biermann K, Pauwels P, De Herder WW, Hofland LJ, Peeters M, et al. 2019 Hotspot DAXX, PTCH2 and CYFIP2 mutations in pancreatic neuroendocrine neoplasms. Endocrine-Related Cancer 26 1-12. (https://doi. org/10.1530/ERC-18-0120)

Vanhaesebroeck B, Stephens L \& Hawkins P 2012 PI3K signalling: the path to discovery and understanding. Nature Reviews Molecular Cell Biology 13 195-203. (https://doi.org/10.1038/ nrm3290)

Verbeke CS 2010 Endocrine tumours of the pancreas. Histopathology 56 669-682. (https://doi.org/10.1111/j.1365-2559.2010.03490.x)

Vézina C, Kudelski A \& Sehgal SN 1975 Rapamycin (AY-22,989), a new antifungal antibiotic. I. Taxonomy of the producing streptomycete and isolation of the active principle. Journal of Antibiotics $\mathbf{2 8}$ 721-726. (https://doi.org/10.7164/antibiotics.28.721)

Villaume K, Blanc M, Gouysse G, Walter T, Couderc C, Nejjari M, Vercherat C, Cordier-Bussat M, Roche C \& Scoazec JY 2010 VEGF secretion by neuroendocrine tumor cells is inhibited by octreotide and by inhibitors of the PI3K/AKT/mTOR pathway. Neuroendocrinology 91 268-278. (https://doi. org/10.1159/000289569)

Vitale G, Gaudenzi G, Dicitore A, Cotelli F, Ferone D \& Persani L 2014 Zebrafish as an innovative model for neuroendocrine tumors. Endocrine-Related Cancer 21 R67-R83. (https://doi.org/10.1530/ERC13-0388)

Vitale G, Dicitore A, Pepe D, Gentilini D, Grassi ES, Borghi MO, Gelmini G, Cantone MC, Gaudenzi G, Misso G, et al. 2017 Synergistic activity of everolimus and 5-aza-2'-deoxycytidine in medullary thyroid carcinoma cell lines. Molecular Oncology 11 1007-1022. (https://doi.org/10.1002/1878-0261.12070)

de Vries C, Escobedo JA, Ueno H, Houck K, Ferrara N \& Williams LT 1992 The fms-like tyrosine kinase, a receptor for vascular endothelial growth factor. Science 255 989-991. (https://doi.org/10.1126/ science.1312256)

Wagle N, Grabiner BC, Van Allen EM, Hodis E, Jacobus S, Supko JG, Stewart M, Choueiri TK, Gandhi L, Cleary JM, et al. 2014 Activating mTOR mutations in a patient with an extraordinary response on a phase I trial of everolimus and pazopanib. Cancer Discovery 4 546-553. (https://doi.org/10.1158/2159-8290.CD-13-0353)

Wang DG 1999 Apoptosis in neuroendocrine tumours. Clinical Endocrinology 51 1-9. (https://doi. org/10.1046/j.1365-2265.1999.00756.x)

Wang GL \& Semenza GL 1995 Purification and characterization of hypoxia-inducible factor 1. Journal of Biological Chemistry $\mathbf{2 7 0}$ 1230-1237. (https://doi.org/10.1074/jbc.270.3.1230)

Wang X, Yue P, Young AK, Fu H, Khuri FR \& Sun SY 2008 Enhancing mammalian target of rapamycin (mTOR)-targeted cancer therapy by preventing $\mathrm{mTOR} /$ raptor inhibition-initiated, $\mathrm{mTOR} /$ rictorindependent Akt activation. Cancer Research 68 7409-7418. (https://doi.org/10.1158/0008-5472.CAN-08-1522)

Wang H, Zhang Q, Wen Q, Zheng Y, Philip L, Jiang H, Lin J \& Zheng WH 2012 Proline-rich Akt substrate of 40kDa (PRAS40): a 
novel downstream target of PI3k/Akt signaling pathway. Cellular Signalling 24 17-24. (https://doi.org/10.1016/j.cellsig.2011.08.010)

Wang X, Zhang L, O'neill A, Bahamon B, Alsop DC, Mier JW, Goldberg SN, Signoretti S, Atkins MB, Wood CG, et al. 2013 Cox-2 inhibition enhances the activity of sunitinib in human renal cell carcinoma xenografts. British Journal of Cancer 108 319-326. (https:// doi.org/10.1038/bjc.2012.591)

Wang Z, Chen H, Zhou N, Zhang T, Ren P \& Chen G 2018 H727 multicellular spheroids and its resistance to antitumor drugs sunitinib and axitinib. Journal of Nanoscience and Nanotechnology 18 8078-8084. (https://doi.org/10.1166/jnn.2018.16030)

Wernig G, Gonneville JR, Crowley BJ, Rodrigues MS, Reddy MM, Hudon HE, Walz C, Reiter A, Podar K, Royer Y, et al. 2008 The Jak2V617F oncogene associated with myeloproliferative diseases requires a functional FERM domain for transformation and for expression of the Myc and Pim proto-oncogenes. Blood 111 3751-3759. (https://doi.org/10.1182/blood-2007-07-102186)

Wiedmer T, Blank A, Pantasis S, Normand L, Bill R, Krebs P, Tschan MP, Marinoni I \& Perren A 2017 Autophagy inhibition improves sunitinib efficacy in pancreatic neuroendocrine tumors via a lysosome-dependent mechanism. Molecular Cancer Therapeutics.16 2502-2515. (https://doi.org/10.1158/1535-7163. MCT-17-0136)

Wilting RH \& Dannenberg JH 2012 Epigenetic mechanisms in tumorigenesis, tumor cell heterogeneity and drug resistance. Drug Resistance Updates 15 21-38. (https://doi.org/10.1016/j. drup.2012.01.008)

Wlodarchak N \& Xing Y 2016 PP2A as a master regulator of the cell cycle. Critical Reviews in Biochemistry and Molecular Biology $\mathbf{5 1}$ 162-184. (https://doi.org/10.3109/10409238.2016.1143913)

Xu-Monette ZY, Zhang M, Li J \& Young KH 2017 PD-1/PD-L1 blockade: have we found the key to unleash the antitumor immune response? Frontiers in Immunology 8 1597. (https://doi.org/10.3389/ fimmu.2017.01597)

Xu CX, Li Y, Yue P, Owonikoko TK, Ramalingam SS, Khuri FR \& Sun SY 2011 The combination of RAD001 and NVP-BEZ235 exerts synergistic anticancer activity against non-small cell lung cancer in vitro and in vivo. PLoS ONE 6 e20899. (https://doi.org/10.1371/ journal.pone.0020899)

Yang Q, Inoki K, Kim E \& Guan K-L 2006 TSC1/TSC2 and Rheb have different effects on TORC1 and TORC2 activity. PNAS 103 6811-6816. (https://doi.org/10.1073/pnas.0602282103)

Yang Z, Chen H, Huo L, Yang Z, Bai Y, Fan X, Ni B, Fang L, Hu J, Peng J, et al. 2015 Epigenetic inactivation and tumor-suppressor behavior of NGFR in human colorectal cancer. Molecular Cancer Research 13 107-119. (https://doi.org/10.1158/1541-7786.MCR-13-0247)

Yao JC, Phan AT, Chang DZ, Wolff RA, Hess K, Gupta S, Jacobs C, Mares JE, Landgraf AN, Rashid A, et al. 2008 Efficacy of RAD001 (everolimus) and octreotide LAR in advanced low- to intermediategrade neuroendocrine tumors: results of a phase II study. Journal of Clinical Oncology 26 4311-4318. (https://doi.org/10.1200/ JCO.2008.16.7858)

Yao JC, Lombard-Bohas C, Baudin E, Kvols LK, Rougier P, Ruszniewski P, Hoosen S, St Peter J, Haas T, Lebwohl D, et al. 2010a Daily oral everolimus activity in patients with metastatic pancreatic neuroendocrine tumors after failure of cytotoxic chemotherapy: a phase II trial. Journal of Clinical Oncology 28 69-76. (https://doi. org/10.1200/JCO.2009.24.2669)

Yao JC, Phan AT, Fogleman D, Ng CS, Jacobs CB, Dagohoy CD, Leary C \& Hess KR $2010 b$ Randomized run-in study of bevacizumab (B) and everolimus (E) in low- to intermediate-grade neuroendocrine tumors (LGNETs) using perfusion CT as functional biomarker. Journal of Clinical Oncology 28 4002. (https://doi.org/10.1200/jco.2010.28.15_suppl.4002)

Yao JC, Shah MH, Ito T, Bohas CL, Wolin EM, Van Cutsem E, Hobday TJ, Okusaka T, Capdevila J, de Vries EGE, et al. 2011 Everolimus for advanced pancreatic neuroendocrine tumors. New England Journal of Medicine 364 514-523. (https://doi.org/10.1056/ NEJMoa1009290)

Yao JC, Phan AT, Jehl V, Shah G \& Meric-Bernstam F 2013 Everolimus in advanced pancreatic neuroendocrine tumors: the clinical experience. Cancer Research 73 1449-1453. (https://doi.org/10.1158/0008-5472. CAN-12-3923)

Yao JC, Fazio N, Singh S, Buzzoni R, Carnaghi C, Wolin E, Tomasek J, Raderer M, Lahner H, Voi M, et al. 2016 Everolimus for the treatment of advanced, non-functional neuroendocrine tumours of the lung or gastrointestinal tract (RADIANT-4): a randomised, placebo-controlled, phase 3 study. Lancet 387 968-977. (https://doi. org/10.1016/S0140-6736(15)00817-X)

Yao JC, Moran C, Guthrie KA, McDonough S, Strosberg JR, Kulke MH, Chan JA, Loconte N, McWilliams RR, Wolin EM, et al. 2017 Phase III prospective randomized comparison trial of depot octreotide plus interferon Alfa- $2 \mathrm{~b}$ versus depot octreotide plus bevacizumab in patients with advanced carcinoid tumors: SWOG S0518. Journal of Clinical Oncology 35 1695-1703. (https://doi.org/10.1200/ JCO.2016.70.4072)

Yoo C, Cho H, Song MJ, Hong SM, Kim KP, Chang HM, Chae H, Kim TW, Hong YS, Ryu MH, et al. 2017 Efficacy and safety of everolimus and sunitinib in patients with gastroenteropancreatic neuroendocrine tumor. Cancer Chemotherapy and Pharmacology 79 139-146. (https://doi.org/10.1007/s00280-016-3215-3)

Yu K, Toral-Barza L, Shi C, Zhang W-G, Lucas J, Shor B, Kim J, Verheijen J, Curran K, Malwitz DJ, et al. 2009 Biochemical, cellular, and in vivo activity of novel ATP-competitive and selective inhibitors of the mammalian target of rapamycin. Cancer Research 69 6232-6240. (https://doi.org/10.1158/0008-5472.CAN-09-0299)

Yu Y, Yoon S-O, Poulogiannis G, Yang Q, Ma XM, Villén J, Kubica N, Hoffman GR, Cantley LC, Gygi SP, et al. 2011 Phosphoproteomic analysis identifies Grb10 as an mTORC1 substrate that negatively regulates insulin signaling. Science 332 1322-1326. (https://doi. org/10.1126/science.1199484)

Zhang F, Beharry ZM, Harris TE, Lilly MB, Smith CD, Mahajan S \& Kraft AS 2009 PIM1 protein kinase regulates PRAS40 phosphorylation and mTOR activity in FDCP1 cells. Cancer Biology and Therapy 8 846-853. (https://doi.org/10.4161/cbt.8.9.8210)

Zhou BP, Liao Y, Xia W, Spohn B, Lee MH \& Hung MC 2001 Cytoplasmic localization of p21 CIP1/WAF1 by Akt-induced phosphorylation in HER-2/neu-overexpressing cells. Nature Cell Biology 3 245-252. (https://doi.org/10.1038/35060032)

Zibelman M, Wong YN, Devarajan K, Malizzia L, Corrigan A, Olszanski AJ, Denlinger CS, Roethke SK, Tetzlaff CH \& Plimack ER 2015 Phase I study of the mTOR inhibitor ridaforolimus and the HDAC inhibitor vorinostat in advanced renal cell carcinoma and other solid tumors. Investigational New Drugs 33 1040-1047. (https:// doi.org/10.1007/s10637-015-0261-3)

Zitzmann K, Rüden J von, Brand S, Göke B, Lichtl J, Spöttl G \& Auernhammer CJ 2010 Compensatory activation of Akt in response to mTOR and Raf inhibitors - a rationale for dualtargeted therapy approaches in neuroendocrine tumor disease. Cancer Letters 295 100-109. (https://doi.org/10.1016/j. canlet.2010.02.018)

Received in final form 13 December 2018

Accepted 21 December 2018

Accepted Preprint published online 21 December 2018 https://erc.bioscientifica.com https://doi.org/10.1530/ERC-18-0420 (c) 2019 Society for Endocrinology Published by Bioscientifica Ltd. Printed in Great Britain 